\title{
Gene Polymorphisms in Chronic Periodontitis
}

\author{
Marja L. Laine, ${ }^{1}$ Bruno G. Loos, ${ }^{2}$ and W. Crielaard ${ }^{1}$ \\ ${ }^{1}$ Department of Oral Microbiology, Academic Center for Dentistry Amsterdam (ACTA), University of Amsterdam and Vrije University, \\ 1081 BT Amsterdam, The Netherlands \\ ${ }^{2}$ Department of Periodontology, Academic Center for Dentistry Amsterdam (ACTA), University of Amsterdam and Vrije University, \\ 1081 BT Amsterdam, The Netherlands
}

Correspondence should be addressed to Marja L. Laine, ml.laine@vumc.nl

Received 29 June 2009; Revised 9 November 2009; Accepted 6 January 2010

Academic Editor: Barbara Noack

Copyright ( 2010 Marja L. Laine et al. This is an open access article distributed under the Creative Commons Attribution License, which permits unrestricted use, distribution, and reproduction in any medium, provided the original work is properly cited.

\begin{abstract}
We aimed to conduct a review of the literature for gene polymorphisms associated with chronic periodontitis (CP) susceptibility. A comprehensive search of the literature in English was performed using the keywords: periodontitis, periodontal disease, combined with the words genes, mutation, or polymorphism. Candidate gene polymorphism studies with a case-control design and reported genotype frequencies in CP patients were searched and reviewed. There is growing evidence that polymorphisms in the IL1, IL6, IL10, vitamin D receptor, and CD14 genes may be associated with CP in certain populations. However, carriage rates of the rare $(R)$-allele of any polymorphism varied considerably among studies and most of the studies appeared under-powered and did not correct for other risk factors. Larger cohorts, well-defined phenotypes, control for other risk factors, and analysis of multiple genes and polymorphisms within the same pathway are needed to get a more comprehensive insight into the contribution of gene polymorphisms in CP.
\end{abstract}

\section{Introduction}

Periodontitis like many other common diseases (e.g., Crohn's disease, cardiovascular diseases, diabetes) is considered to be a complex multifactorial disease. Typical for complex human diseases is that they mostly have a relatively mild phenotype and are slowly progressing and chronic in nature. Furthermore, these diseases are of relative late of onset (i.e., postjuvenile or adult onset) and are relatively common. The phenotype of the complex diseases is determined by both genetic and the environmental factors that affect the individual. Although pathogenic bacteria and various other environmental factors (e.g., smoking and stress) [1] are involved in pathogenesis of periodontitis, also genetic factors are evidenced in the aetiology of periodontitis $[2,3]$.

Understanding of the interplay between the host and oral bacteria is essential to the understanding of the pathogenesis of periodontal disease. Periodontopathic bacteria initiate and repeatedly attack the host, which subsequently reacts with immune response and may slowly destruct by the action of the inflammatory process itself. However, the presence of pathogenic subgingival bacteria alone does not result in periodontal destruction in most cases. Therefore, although bacteria are essential for the initiation of periodontitis, the amount of plaque and the species of bacteria does not necessarily correlate with disease severity [4]. Each person may have an individual dose dependend response to the bacterial challenge that determines his/her susceptibility to periodontitis. Most individuals are resistant to the disease and will not develop periodontitis.

There are a large number of scientific papers searching for the role of genes and their variants (polymorphisms) in host responses in periodontitis, and in the progression of the disease. The genetic polymorphisms may in some situations cause a change in the protein or its expression possibly resulting in alterations in innate and adaptive immunity and may thus be deterministic in disease outcome. Genetic polymorphisms may also be protective for a disease. The pathophysiology of periodontitis, as of other complex diseases, is characterized by various biological pathways leading to the same clinical phenomena. Multiple genes and their polymorphisms may all have a small overall contribution and relative risk to disease susceptibility and severity. Complex diseases are typically polygenic [23]. The 
TABLE 1: IL1A -889 (+4845) C>T gene polymorphisms and carriage rate of the Rare $(R)$-allele in case-control studies and association with susceptibility to chronic periodontitis.

\begin{tabular}{|c|c|c|c|c|c|c|}
\hline \multirow[b]{2}{*}{$\begin{array}{l}\text { Ethnicity } \\
\text { of subjects }\end{array}$} & \multicolumn{2}{|c|}{ Patients } & \multicolumn{2}{|c|}{ Controls } & \multirow[b]{2}{*}{$\begin{array}{c}\text { Associated } \\
\text { with periodontitis }\end{array}$} & \multirow[b]{2}{*}{ Reference } \\
\hline & $n$ & $\begin{array}{l}R \text {-allele } \\
\text { carriage }\end{array}$ & $N$ & $\begin{array}{l}R \text {-allele } \\
\text { carriage }\end{array}$ & & \\
\hline Caucasian & $32^{2}$ & $43 \%$ & 32 & $38 \%$ & - & Gore et al.1998 [5] \\
\hline Caucasian & $105^{2}$ & $64 \%$ & 53 & $60 \%$ & $-\left(+^{4}\right)$ & Laine et al. 2001 [6] \\
\hline Caucasian & 61 & $43 \%$ & 800 & $50 \%$ & - & Thomson et al. 2001 [7] \\
\hline Caucasian & $84^{1}$ & $48 \%$ & 60 & $45 \%$ & - & Rogers et al. 2002 [8] \\
\hline Caucasian & 45 & $53 \%$ & 110 & $43 \%$ & - & Sakellari et al. 2003 [9] \\
\hline Caucasian & 57 & $72 \%$ & 100 & $56 \%$ & - & Brett et al. 2005 [10] \\
\hline Caucasian & $330^{3}$ & $44 \%$ & 101 & $35 \%$ & - & Lopez et al. 2005 [11] \\
\hline Caucasian & 56 & $54 \%$ & 90 & $49 \%$ & - & Sakellari et al. 2006 [12] \\
\hline Caucasian & 51 & $55 \%$ & 178 & $43 \%$ & - & Tervonen et al. 2007 [13] \\
\hline Caucasian & 97 & $90 \%$ & 97 & $79 \%$ & + & Wagner et al. 2007 [14] \\
\hline Caucasian & $893^{2}$ & $54 \%$ & 493 & $49 \%$ & - & Struch et al. 2008 [15] \\
\hline Caucasian & $51^{1}$ & $71 \%$ & 168 & $60 \%$ & - & Geismar et al. 2008 [16] \\
\hline Mixed $^{1}$ & 83 & $69 \%$ & 37 & $52 \%$ & - & Shirodaria et al. 2000 [17] \\
\hline Asian (Thai) & 54 & $8 \%$ & 43 & $23 \%$ & - & Anusaksathien et al. 2003 [18] \\
\hline Japanese & $58^{3}$ & $14 \%$ & 44 & $16 \%$ & - & Kobayashi et al. 2007 [19] \\
\hline Japanese & $100^{3}$ & $20 \%$ & 100 & $16 \%$ & - & Kobayashi et al. 2007 [20] \\
\hline Brazilian & 29 & $14 \%$ & 17 & $23 \%$ & - & Gonçalves et al. 2006 [21] \\
\hline Brazilian & 67 & $60 \%$ & 41 & $41 \%$ & + & Moreira et al. 2007 [22] \\
\hline
\end{tabular}

$\mathrm{nr}=$ not reported. $-=$ association not found. $+=$ association found.

${ }^{1} 63 \%$ Caucasian; 22\% Asian; 15\% Afro-Caribean.

${ }^{2}$ Cases diagnosed as adult periodontitis.

${ }^{3}$ Cases diagnosed as mixed periodontitis status.

${ }^{4}$ An association with periodontitis was found for combined genotype: carriage of $R$-allele for $I L 1 A-889, I L-1 B+3954$, and $I L 1 R N$ in a subgroup of patients being nonsmokers, and at the same time culture negative for P. gingivalis and A. actinomycetemcomitans.

disease genes in complex diseases are therefore considered modifying disease genes [24]. It is important to realize that the number and type of modifying disease genes for the same disease may not be same in different ethnic populations. In the present review we explore and summarize literature up to April 2009 on putative genetic risk factors in chronic periodontitis $(\mathrm{CP})$ susceptibility.

\section{The Role of Genetics in Chronic Periodontitis}

Evidence for the role of genetic component in chronic (adult) periodontitis has been conducted from twin and family studies. The twin model is probably the most powerful method to study genetic aspects of any disease, including periodontal disease. Michalowicz et al. evaluated the periodontal conditions (attachment loss, pocket depth, gingival index, and plaque index) of 110 adult twins with a mean age of 40 years ranging from 16 to 70 years [3]. The results indicate that between $38 \%$ and $82 \%$ of the population variance for these measures may be attributed to genetic factors. In a study on 117 adult twin pairs [2] the analysis included the evaluation of the environmental factors like smoking and utilization of dental services. The results showed that chronic (adult) periodontitis was estimated to have approximately $50 \%$ heritability, which was unaltered following adjustments for behavioral variables including smoking. In contrast, there was no evidence of heritability for gingivitis after behavioral covariates such as utilization dental care and smoking were incorporated in the analysis.

Velden et al. [33] studied with a family study design the effect of sibling relationship on the periodontal condition in a group of young Indonesians deprived from regular dental care. The results of the analysis suggest that also in less severe forms of periodontitis there may be a genetic background for the disease. Also in a Dutch population epidemiological studies have suggested that chronic (adult) periodontitis aggregates in families [34].

From both the twin and family studies it can be concluded that the basis for familial aggregation of periodontitis appears not bacterial/environmental/behavioral in nature; rather, genetics seem to form the basis for the familial aggregation of periodontitis.

\section{Strategy of the Recovery of Published Data}

A comprehensive literature search on the PubMed database up to April 2009 was conducted using the keywords: Periodontitis, Periodontal disease, in combination with the words Genes, Mutation, or Polymorphism. The studies selected for the review (1) were written in English, (2) 
TABLE 2: IL1B +3954 (+3953) C>T gene polymorphisms and carriage rate of the Rare $(R)$-allele in case-control studies and association with susceptibility to chronic periodontitis.

\begin{tabular}{|c|c|c|c|c|c|c|}
\hline \multirow[b]{2}{*}{$\begin{array}{l}\text { Ethnicity } \\
\text { of subjects }\end{array}$} & \multicolumn{2}{|c|}{ Patients } & \multicolumn{2}{|c|}{ Controls } & \multirow[b]{2}{*}{$\begin{array}{c}\text { Associated } \\
\text { with periodontitis }\end{array}$} & \multirow[b]{2}{*}{ Reference } \\
\hline & $n$ & $\begin{array}{l}R \text {-allele } \\
\text { carriage }\end{array}$ & $n$ & $\begin{array}{l}R \text {-allele } \\
\text { carriage }\end{array}$ & & \\
\hline Caucasian & $32^{1}$ & $43 \%$ & 32 & $38 \%$ & - & Gore et al. 1998 [5] \\
\hline Caucasian & $40^{1}$ & $50 \%$ & 45 & $27 \%$ & + & Galbraith et al. 1999 [25] \\
\hline Caucasian & $105^{1}$ & $49 \%$ & 53 & $45 \%$ & $-\left(+^{3}\right)$ & Laine et al. 2001 [6] \\
\hline Caucasian & 61 & $34 \%$ & 800 & $41 \%$ & - & Thomson et al. 2001 [7] \\
\hline Caucasian & $84^{1}$ & $35 \%$ & 60 & $40 \%$ & $+^{4}$ & Rogers et al. 2002 [8] \\
\hline Caucasian & $28^{1}$ & $46 \%$ & 33 & $48 \%$ & - & Gonzales et al. 2003 [26] \\
\hline Caucasian & 45 & $49 \%$ & 110 & $50 \%$ & - & Sakellari et al. 2003 [9] \\
\hline Caucasian & 57 & $42 \%$ & 100 & $41 \%$ & - & Brett et al. 2005 [10] \\
\hline Caucasian & $330^{2}$ & $30 \%$ & 101 & $13 \%$ & + & Lopez et al. 2005 [11] \\
\hline Caucasian & 32 & $34 \%$ & 52 & $40 \%$ & - & Droździk et al. 2006 [27] \\
\hline Caucasian & 13 & $33 \%$ & 13 & $33 \%$ & - & Gustafsson et al. 2006 [28] \\
\hline Caucasian & 56 & $41 \%$ & 90 & $44 \%$ & - & Sakellari et al. 2006 [12] \\
\hline Caucasian & 51 & $49 \%$ & 178 & $44 \%$ & - & Tervonen et al. 2007 [13] \\
\hline Caucasian & 97 & $74 \%$ & 97 & $43 \%$ & + & Wagner et al. 2007 [14] \\
\hline Caucasian & $51^{1}$ & $57 \%$ & 168 & $43 \%$ & - & Geismar et al. 2008 [16] \\
\hline Caucasian & $893^{1}$ & $44 \%$ & 493 & $39 \%$ & -5 & Struch et al. 2008 [15] \\
\hline Asian (Thai) & 54 & $0 \%$ & 43 & $2 \%$ & - & Anusaksathien et al. 2003 [18] \\
\hline Japanese & $64^{1}$ & $6 \%$ & 64 & $10 \%$ & - & Soga et al. 2003 [29] \\
\hline Japanese & $58^{2}$ & $5 \%$ & 44 & $7 \%$ & - & Kobayashi et al. 2007 [19] \\
\hline Japanese & $100^{2}$ & $6 \%$ & 100 & $6 \%$ & - & Kobayashi et al. 2007 [20] \\
\hline Brazilian & 52 & $44 \%$ & 31 & $23 \%$ & + & Moreira et al. 2005 [30] \\
\hline Brazilian & 29 & $28 \%$ & 17 & $18 \%$ & - & Gonçalves et al. 2006 [21] \\
\hline Brazilian & 117 & $39 \%$ & 175 & $31 \%$ & - & Ferreira et al. 2008 [31] \\
\hline Indian & 30 & $30 \%$ & 31 & $23 \%$ & - & Kaarthikeyan et al. 2009 [32] \\
\hline
\end{tabular}

$\mathrm{nr}=$ not reported. $-=$ association not found. $+=$ association found.

${ }^{1}$ Cases diagnosed as adult periodontitis.

${ }^{2}$ Cases diagnosed as mixed periodontitis status.

${ }^{3} \mathrm{An}$ association with periodontitis was found for combined genotype: carriage of $R$-allele for $I L 1 A-889, I L 1 B+3954$, and $I L 1 R N$ in a subgroup of patients being nonsmokers, and at the same time culture negative for P. gingivalis and A. actinomycetemcomitans.

${ }^{4} N$-allele is associated with CP.

${ }^{5} R$-allele is not quit associated with $\mathrm{CP}(P=.07)$.

had a case-control design including patients with chronic $(\mathrm{CP})$ or adult (AP) periodontitis, and (3) reported genotype distribution.

In the preparation of this review we encountered various nomenclatures for the diagnosis of cases and controls, and during the years, the nomenclature for the diagnosis of the various forms of periodontitis has changed. In this paper we have used the diagnosis of periodontitis from the original manuscripts as much as possible. We focussed on the role of genetic polymorphisms (mainly single nucleotide polymorphisms [SNPs]) in chronic periodontitis (CP) susceptibility.

In the present review, the most common variant of the polymorphic locus in the study population is nominated as a normal variant ( $N$-allele). Thus, if a locus is, for example, bi-allelic, the less frequent allele is designated as a rare variant ( $R$-allele) but must occur with a frequency of $>1 \%$ in the population. We present in the tables the frequency of the carriage rate of the $R$-allele (frequency of $N / R$ and $R / R$ genotypes) among cases and controls. In addition we present in the tables whether or not the authors of the cited papers have reported statistically significant differences between cases and controls for a given $R$-allele.

Most genetic research in periodontitis has focused on gene polymorphisms that play a role in the immune system, tissue destructive processes, or metabolism mechanisms. Tables 1-12 present the candidate gene polymorphisms investigated in relation to $\mathrm{CP}$ susceptibility. In this review a polymorphism was considered to be associated with $\mathrm{CP}$ susceptibility if a polymorphism has been investigated in several studies and the association has been replicated at least once. Below we discuss the findings of various epidemiological studies that were undertaken to further understand the roles of gene polymorphisms in susceptibility to chronic periodontitis. 
TABLE 3: IL1B -511 (-31) and IL1RN VNTR (+2018) gene polymorphisms and carriage rate of the Rare $(R)$-allele in case-control studies and association with susceptibility to chronic periodontitis.

\begin{tabular}{|c|c|c|c|c|c|c|c|}
\hline \multirow[b]{2}{*}{$\begin{array}{l}\text { IL1 gene } \\
\text { polymorphism }\end{array}$} & \multirow[b]{2}{*}{ Ethnicity of subjects } & \multicolumn{2}{|c|}{ Patients } & \multicolumn{2}{|c|}{ Controls } & \multirow[b]{2}{*}{$\begin{array}{c}\text { Associated } \\
\text { with periodontitis }\end{array}$} & \multirow[b]{2}{*}{ Reference } \\
\hline & & $n$ & $\begin{array}{l}R \text {-allele } \\
\text { carriage }\end{array}$ & $n$ & $\begin{array}{l}R \text {-allele } \\
\text { carriage }\end{array}$ & & \\
\hline \multirow{4}{*}{$B-511(-31) \mathrm{C}>\mathrm{T}$} & Caucasian & $32^{1}$ & $59 \%$ & 32 & $59 \%$ & - & Gore et al. 1998 [5] \\
\hline & Caucasian & 57 & $53 \%$ & 100 & $49 \%$ & - & Brett et al. 2005 [10] \\
\hline & Caucasian & $51^{1}$ & $43 \%$ & 168 & $56 \%$ & - & Geismar et al. 2008 [16] \\
\hline & Japanese & $64^{1}$ & $67 \%$ & 64 & $78 \%$ & - & Soga et al. 2003 [29] \\
\hline \multirow{5}{*}{$R N$ VNTR $(+2018 \mathrm{C}>\mathrm{T})$} & Caucasian & $105^{1}$ & $46 \%$ & 53 & $38 \%$ & $-\left(+^{3}\right)$ & Laine et al. 2001 [6] \\
\hline & Caucasian & 51 & $45 \%$ & 190 & $7 \%$ & + & Berdeli et al. 2006 [35] \\
\hline & Caucasian & 56 & $45 \%$ & 90 & $30 \%$ & - & Sakellari et al. 2006 [12] \\
\hline & Caucasian & $51^{1}$ & $34 \%$ & 168 & $44 \%$ & - & Geismar et al. 2008 [16] \\
\hline & Japanese & $100^{2}$ & $6 \%$ & 100 & $13 \%$ & - & Kobayashi et al. 2007 [20] \\
\hline
\end{tabular}

$\mathrm{nr}=$ not reported. $-=$ association not found. $+=$ association found.

${ }^{1}$ Cases diagnosed as adult periodontitis.

${ }^{2}$ Cases diagnosed as mixed periodontitis status.

${ }^{3}$ An association with periodontitis was found for combined genotype: carriage of $R$-allele for $I L 1 A-889, I L 1 B+3954$, and $I L 1 R N$ in a subgroup of patients being non-smokers and culture negative for P. gingivalis and A. actinomycetemcomitans.

TABLE 4: IL1 composite genotype, that is, Rare (R)-allele carriage at IL1A -889 (+4845) and IL1B +3954 (+3953) [36], in case-control studies and association with susceptibility to chronic periodontitis.

\begin{tabular}{|c|c|c|c|c|c|c|}
\hline \multirow[b]{2}{*}{$\begin{array}{l}\text { Ethnicity } \\
\text { of subjects }\end{array}$} & \multicolumn{2}{|c|}{ Patients } & \multicolumn{2}{|c|}{ Controls } & \multirow[b]{2}{*}{$\begin{array}{c}\text { Associated } \\
\text { with periodontitis }\end{array}$} & \multirow[b]{2}{*}{ Reference } \\
\hline & $n$ & $\begin{array}{l}R \text {-allele } \\
\text { carriage }\end{array}$ & $n$ & $\begin{array}{l}R \text {-allele } \\
\text { carriage }\end{array}$ & & \\
\hline Caucasian & $32^{2}$ & $34 \%$ & 32 & $28 \%$ & - & Gore et al. 1998 [5] \\
\hline Caucasian $^{1}$ & 44 & $41 \%$ & 46 & $28 \%$ & + & McDevitt et al. 2000 [37] \\
\hline Caucasian & $105^{2}$ & $46 \%$ & 53 & $42 \%$ & - & Laine et al. 2001 [6] \\
\hline Caucasian & $132^{3}$ & $45 \%$ & 73 & $42 \%$ & - & Papapanou et al. 2001 [38] \\
\hline Caucasian & 61 & $28 \%$ & 800 & $35 \%$ & - & Thomson et al. 2001 [7] \\
\hline Caucasian & $84^{2}$ & $26 \%$ & 60 & $30 \%$ & - & Rogers et al. 2002 [8] \\
\hline Caucasian & 402 & $38 \%$ & 414 & $34 \%$ & $-\left(+^{4}\right)$ & Meisel et al. 2003 [39] \\
\hline Caucasian & 45 & $34 \%$ & 110 & $30 \%$ & - & Sakellari et al. 2003 [9] \\
\hline Caucasian & $330^{3}$ & $26 \%$ & 101 & $10 \%$ & + & Lopez et al. 2005 [11] \\
\hline Caucasian & 56 & $41 \%$ & 90 & $44 \%$ & - & Sakellari et al. 2006 [12] \\
\hline Chinese & $244^{2}$ & $0 \%$ & 56 & $3 \%$ & - & Armitage et al. 2000 [40] \\
\hline Asian (Thai) & 54 & $0 \%$ & 43 & $2 \%$ & - & Anusaksathien et al. 2003 [18] \\
\hline Japanese & $100^{3}$ & $0.2 \%$ & 100 & $0.2 \%$ & - & Kobayashi et al. 2007 [20] \\
\hline Indian & 90 & $14 \%$ & 30 & $0 \%$ & + & Agrawal et al. 2006 [41] \\
\hline Brazilian & 29 & $3 \%$ & 17 & $12 \%$ & - & Gonçalves et al. 2006 [21] \\
\hline
\end{tabular}

$\mathrm{nr}=$ not reported. $-=$ association not found. $+=$ association found.

${ }^{1} 82 \%$ of study population is of Caucasian heritage; results found after multiple logistic regression analysis correcting for smoking status and age.

${ }^{2}$ Cases diagnosed as adult periodontitis.

${ }^{3}$ Cases diagnosed as mixed periodontitis status.

${ }^{4}$ In smokers.

\section{Candidate Genes in Relation to Chronic Periodontitis (CP)}

4.1. Polymorphisms in the IL1 Gene Cluster. Interleukin-1 (IL-1) is a potent proinflammatory mediator that is mainly released by monocytes, macrophages, and dendritic cells. Levels of IL- $1 \alpha$ and IL- $1 \beta$, (proinflammatory cytokines) and IL-1/IL-receptor antagonist (RA, antiinflammatory cytokine) ratio have been found to be increased in diseased periodontal tissues and gingival grevicular fluid $[53,54]$. The genes encoding for the proteins IL- $1 \alpha$, IL- $1 \beta$, and IL-1RA are located in close proximity in the IL1 gene cluster on chromosome 2q13-q21. The IL1A -889 and IL1B $+3953 R$-alleles have been shown to increase and the IL1RN VNTR $R$-alleles to decrease gene transcription or the protein production levels $[17,55,56]$ resulting in the $R$-allele carrier individuals in a more pronounced IL-1 pro-inflammatory response. 
TABLE 5: TNFA gene polymorphisms and carriage rate of the Rare $(R)$-allele in case-control studies and association with susceptibility to chronic periodontitis.

\begin{tabular}{|c|c|c|c|c|c|c|c|}
\hline \multirow[b]{2}{*}{$\begin{array}{l}\text { TNFA gene } \\
\text { polymorphism }\end{array}$} & \multirow[b]{2}{*}{$\begin{array}{l}\text { Ethnicity } \\
\text { of subjects }\end{array}$} & \multicolumn{2}{|c|}{ Patients } & \multicolumn{2}{|c|}{ Controls } & \multirow[b]{2}{*}{$\begin{array}{c}\text { Associated } \\
\text { with periodontitis }\end{array}$} & \multirow[b]{2}{*}{ Reference } \\
\hline & & $n$ & $\begin{array}{l}R \text {-allele } \\
\text { carriage }\end{array}$ & $n$ & $\begin{array}{l}R \text {-allele } \\
\text { carriage }\end{array}$ & & \\
\hline$-1031 \mathrm{~T}>\mathrm{C}$ & Japanese & $64^{2}$ & $36 \%$ & 64 & $22 \%$ & + & Soga et al. 2003 [29] \\
\hline$-863 \mathrm{C}>\mathrm{A}$ & Japanese & $64^{2}$ & $39 \%$ & 64 & $25 \%$ & + & Soga et al. 2003 [29] \\
\hline$-857 \mathrm{C}>\mathrm{T}$ & Japanese & $64^{2}$ & $39 \%$ & 64 & $28 \%$ & + & Soga et al. 2003 [29] \\
\hline$-367 \mathrm{G}>\mathrm{A}$ & Mixed $^{1}$ & 90 & $2 \%$ & 264 & $2 \%$ & - & Craandijk et al. 2002 [42] \\
\hline \multirow{12}{*}{$-308 \mathrm{G}>\mathrm{A}$} & Caucasian & $32^{2}$ & $28 \%$ & 32 & $24 \%$ & - & Galbraith et al. 1998 [43] \\
\hline & Caucasian & $40^{2}$ & $20 \%$ & 45 & $24 \%$ & $+^{3}$ & Galbraith et al. 1999 [25] \\
\hline & Caucasian & 132 & $21 \%$ & 114 & $24 \%$ & - & Fassmann et al. 2003 [44] \\
\hline & Caucasian & 81 & $36 \%$ & 80 & $28 \%$ & - & Folwaczny et al. 2004 [45] \\
\hline & Caucasian & 60 & $22 \%$ & 39 & $18 \%$ & - & Donati et al. 2005 [46] \\
\hline & Caucasian & 57 & $35 \%$ & 100 & $40 \%$ & - & Brett et al. 2005 [10] \\
\hline & Caucasian & 56 & $16 \%$ & 90 & $27 \%$ & - & Sakellari et al. 2006 [12] \\
\hline & Caucasian & 51 & $31 \%$ & 178 & $23 \%$ & - & Tervonen et al. 2007 [13] \\
\hline & Caucasian & 54 & $31 \%$ & 52 & $35 \%$ & - & Schulz et al. 2008 [47] \\
\hline & Mixed $^{1}$ & 90 & $27 \%$ & 264 & $29 \%$ & - & Craandijk et al. 2002 [42] \\
\hline & Japanese & $64^{2}$ & $2 \%$ & 64 & $3 \%$ & - & Soga et al. 2003 [29] \\
\hline & Brazilian & 74 & $31 \%$ & 51 & $44 \%$ & - & De Menezes et al. 2008 [48] \\
\hline \multirow{4}{*}{$-238 \mathrm{G}>\mathrm{A}$} & Caucasian & $32^{2}$ & $6 \%$ & 32 & $6 \%$ & - & Galbraith et al. 1998 [43] \\
\hline & Caucasian & 54 & $9 \%$ & 52 & $15 \%$ & - & Schulz et al. 2008 [47] \\
\hline & Mixed $^{1}$ & 90 & $6 \%$ & 264 & $6 \%$ & - & Craandijk et al. 2002 [42] \\
\hline & Japanese & $64^{2}$ & $0 \%$ & 64 & $3 \%$ & - & Soga et al. 2003 [29] \\
\hline$+489 \mathrm{G}>\mathrm{A}$ & Mixed $^{1}$ & 90 & $24 \%$ & 264 & $19 \%$ & - & Craandijk et al. 2002 [42] \\
\hline
\end{tabular}

$\mathrm{nr}=$ not reported. - = association not found. $+=$ association found.

${ }^{1} 81 \%$ of study population is of Caucasian heritage.

${ }^{2}$ Cases diagnosed as adult periodontitis.

${ }^{3} \mathrm{~N} / \mathrm{N}$ genotype is associated with CP.

The IL1 genotypes appear to be the most studied genetic polymorphisms in CP (Tables 1-4). Kornman et al. [36] reported on a composite genotype, composed of the IL1A -889 and $I L 1 B+3953$ polymorphisms both carrying an $R$-allele, in relation to periodontitis. To date, the following IL1 genetic polymorphisms have been studied in association with chronic periodontitis: IL1A -889 (in linkage disequilibrium with +4845 ), $I L-1 B-511$ (in linkage disequilibrium with -31), IL1B +3954 (also mentioned in the literature as +3953 ), and IL1RN VNTR (in linkage disequilibrium with $+2018)$.

Results of case-control studies in Caucasians and nonCaucasians are presented in Tables 1-4. From the tables it becomes clear that among the different studies even exclusively within Caucasian subjects, considerable variation is seen for the carriage rates of the IL1 R-alleles. For example, for the polymorphic IL1A -889 (+4845) (Table 1), the carriage rate for the $R$-allele varies from $43 \%$ to $90 \%$ in patients and from $35 \%$ to $79 \%$ in controls. The carriage rate of the IL1A -889 $(+4845) R$-allele in Asian populations appears low $(8 \%-23 \%)[18,20]$ in comparison to other populations. The latter finding demonstrates an important issue, that is, the carriage rate of genetic polymorphisms may vary among different ethnic populations. Therefore, possible positive associations between a genetic polymorphism and disease within one population may not necessarily be extrapolated to other populations. Only two studies $[14,22]$ have reported on an association between the carriage rates of the IL1A -889 $R$-alleles and $\mathrm{CP}$ as a single genetic risk factor.

The SNP IL1B +3954 (+3953) was initially proposed as risk factor for periodontitis among Caucasians (Table 2). Nevertheless there are conflicting results. Galbraith et al. [25] found an association between the $R$-allele and periodontitis, and Gore et al. [5] observed an association with the severity of periodontal destruction. Also Lopez et al. [11], Moreira et al. [30], and Wagner et al. [14] have associated the IL1B +3954 R-allele with CP. However, Rogers et al. [8] did not find the association for the $R$-allele but for the $N$-allele in CP. Among Asian subjects, the carriage rate of the IL1B +3954 $(+3953) R$-allele is importantly lower $(\leq 10 \%)[18,20,29]$ than that in Caucasian populations $(13 \%-74 \%)$ (Table 2). Struch et al. [15] have performed a large scale study on the $I L 1 B+3954$ polymorphism in a Caucasian population: in a group of 893 CP patients and 493 controls carriage rates for the $R$-allele were $44 \%$ and $39 \%$, respectively, which was not significant $(P=.07)$.

Four studies have reported carriage rates for the $I L 1 B$ $511(-31) R$-allele, and to date this genetic polymorphism 
TABLE 6: IL4 and IL4RA gene polymorphisms and carriage of the Rare (R)-allele in case-control studies, and association with chronic susceptibility to periodontitis.

\begin{tabular}{|c|c|c|c|c|c|c|c|}
\hline & & \multicolumn{2}{|c|}{ Patients } & \multicolumn{2}{|c|}{ Controls } & \multirow[b]{2}{*}{$\begin{array}{c}\text { Associated } \\
\text { with periodontitis }\end{array}$} & \multirow[b]{2}{*}{ Reference } \\
\hline $\begin{array}{l}\text { IL4 gene } \\
\text { polymorphism }\end{array}$ & Ethnicity of subjects & $n$ & $\begin{array}{l}R \text {-allele } \\
\text { carriage }\end{array}$ & $n$ & $\begin{array}{l}R \text {-allele } \\
\text { carriage }\end{array}$ & & \\
\hline \multirow{3}{*}{$-33 \mathrm{C}>\mathrm{T}$} & Caucasian & 194 & $32 \%$ & 158 & $25 \%$ & $-\left(+^{2}\right)$ & Holla et al. 2008 [49] \\
\hline & Brazilian & 69 & $68 \%$ & 44 & $57 \%$ & - & Scarel-Caminaga et al. 2003 [50] \\
\hline & African-American & $30^{1}$ & $87 \%$ & 30 & $81 \%$ & - & Pontes et al. 2004 [51] \\
\hline \multirow{3}{*}{$-590 \mathrm{C}>\mathrm{T}$} & Caucasian & 194 & $32 \%$ & 158 & $25 \%$ & $-\left(+^{2}\right)$ & Holla et al. 2008 [49] \\
\hline & Iranian & 26 & $33 \%$ & 56 & $52 \%$ & - & Hooshmand et al. 2008 [52] \\
\hline & African-American & $30^{1}$ & $67 \%$ & 30 & $57 \%$ & - & Pontes et al. 2004 [51] \\
\hline VNTR intron 3 & Caucasian & 194 & $31 \%$ & 158 & $25 \%$ & $-\left(+^{2}\right)$ & Holla et al. 2008 [49] \\
\hline RA Q551R & Caucasian & 60 & $45 \%$ & 39 & $39 \%$ & - & Donati et al. 2005 [46] \\
\hline
\end{tabular}

$\mathrm{nr}=$ not reported. $-=$ association not found. $+=$ association found.

${ }^{1}$ Cases diagnosed as mixed periodontitis status.

${ }^{2}$ Haplotype $\mathrm{T}(-590) / \mathrm{T}(-33)$ /allele $2(70 \mathrm{bp})$ is associated with CP $(17.0 \%$ cp versus $11.0 \%$; OR 1.85$)$.

has not been associated with CP (Table 3). The carriage of the $R$-allele was higher among Japanese $(67 \%)$ than among Caucasians (43\%-59\%) $[5,10,16,29]$.

Few studies have investigated polymorphisms in the IL1RN gene, encoding the IL-1RA (Table 3) and again conflicting results are reported. The $R$-allele carriage is associated as a single genetic risk factor with CP $(45 \%$ versus $7 \%$ in controls) in Turkish Caucasians [35]. In combination with $I L 1 A-889$ and IL1B +3954, the IL1RN R-allele was reported to have a relationship with periodontitis susceptibility [6].

Kornman et al. [36] reported that the combined presence of the $R$-allele of the IL1A !gene at nucleotide position 889 and the $R$-allele of the $I L 1 B$. gene at nucleotide position $+3954(+3953)$ was associated with severity of periodontitis in nonsmoking Caucasian patients. This combined carriage rate of the $R$-alleles was designated the IL1 composite genotype [36]. Since that time a considerable number of studies investigating the IL1 composite genotype have been published in Caucasians and non-Caucasians (Table 4). Studies on Caucasian populations have shown prevalence from $10 \%$ to $46 \%$ for the composite genotype, whereas among Asian populations $[18,20,40]$ prevalence of the ILI composite genotype was very low $(\leq 3 \%)$.

After the initial results of Kornman et al. [36], many casecontrol studies have investigated the IL1 composite genotype as a putative risk factor for CP susceptibility, mostly in Caucasian populations (Table 4). Two studies have observed an association between the IL1 composite genotype and periodontitis susceptibility in Caucasians $[11,37]$ and one study in non-Caucasians [41]. Meisel et al. [39] observed the IL1 composite genotype to be associated with periodontitis in Caucasian but only in smokers. However, all other studies have failed to replicate this association (Table 4). Nevertheless, it has also been reported that patients with the IL1 composite genotype more often harbored putative periodontal pathogens and have increased counts of these pathogens [147]. Interestingly, Laine et al. [6] reported increased frequency of the R-alleles of the ILIA, ILIB, and ILIRN genes in non-smoking patients in whom the periodontal pathogens Porphyromonas gingivalis and Aggregatibacter actinomycetemcomitans could not be detected. These latter results suggest that IL1 gene polymorphisms may play a role in the absence of other (putative) risk factors.

Taken altogether, the IL1 gene cluster polymorphisms cannot be considered as risk factors for $\mathrm{CP}$ susceptibility for the worldwide population. However, for Caucasian CP patients the IL1 composite genotype and/or IL1B +3953 genotype may be genetic risk factors. Results of the metaanalysis of Nikolopoulos et al. [148] support also an association between CP and IL1A -889 and IL1B +3953Rallele carriage as well separately as in composite genotype in Caucasians.

4.2. Polymorphisms in the TNFA Gene. Tumor necrosis factor (TNF) is a proinflammatory cytokine that possesses a wide range of immunoregulatory functions. TNF is produced by monocytes, macrophages, and lymphocytes and has the potential to stimulate the production of secondary mediators, including chemokines or cyclooxygenase products, which consequently amplify the degree of inflammation. The TNFA gene is located on chromosome 6 p21.3 within the Major Histocompatibility Complex gene cluster. Several case-control studies in both Caucasians and non-Caucasians have investigated genetic polymorphisms in the TNFA gene as putative risk factors for periodontitis. SNPs in the gene encoding TNFA are mainly studied in the promoter region at positions $-1031,-863,-857,-376,-308$, and -238 but also in the coding region in the first intron at position +489 . The results of these studies are summarized in Table 5 .

The differences in the carriage rate of the $R$-alleles between Japanese and other populations are apparent; at position -308 the $R$-allele carriage rates for Japanese subjects were only $2 \%-3 \%$ (Table 5) [29] and for other populations $18 \%-44 \%[10,12,13,25,43-47]$. For the TNFA -238 the frequencies of $R$-alleles were comparable between different 
TABLE 7: IL6 and IL6R gene polymorphisms and carriage of the Rare $(R)$-allele in case-control studies and association with susceptibility to chronic periodontitis.

\begin{tabular}{|c|c|c|c|c|c|c|c|}
\hline \multirow[b]{2}{*}{$\begin{array}{l}\text { IL6 gene } \\
\text { polymorphism }\end{array}$} & \multirow[b]{2}{*}{$\begin{array}{l}\text { Ethnicity } \\
\text { of subjects }\end{array}$} & \multicolumn{2}{|c|}{ Patients } & \multicolumn{2}{|c|}{ Controls } & \multirow[b]{2}{*}{$\begin{array}{l}\text { Associated } \\
\text { with periodontitis }\end{array}$} & \multirow[b]{2}{*}{ Reference } \\
\hline & & $n$ & $\begin{array}{l}R \text {-allele } \\
\text { carriage }\end{array}$ & $n$ & $\begin{array}{l}R \text {-allele } \\
\text { carriage }\end{array}$ & & \\
\hline \multirow{11}{*}{$-174 \mathrm{G}>\mathrm{C}$} & Caucasian & 148 & $77 \%$ & 107 & $84 \%$ & - & Holla et al. 2004 [57] \\
\hline & Caucasian & 57 & $61 \%$ & 100 & $44 \%$ & + & Brett et al. 2005 [10] \\
\hline & Caucasian & 124 & $42 \%$ & 116 & $28 \%$ & $t^{2}$ & Babel et al. 2006 [58] \\
\hline & Caucasian & 137 & $65 \%$ & 82 & $62 \%$ & - & Wohlfahrt et al. 2006 [59] \\
\hline & Caucasian & 51 & $78 \%$ & 178 & $79 \%$ & - & Tervonen et al. 2007 [13] \\
\hline & Caucasian & 326 & $61 \%$ & 144 & $71 \%$ & $+^{3}$ & \multirow{3}{*}{ Nibali et al. 2009 [60] } \\
\hline & Afro-American & 93 & $10 \%$ & 45 & $16 \%$ & - & \\
\hline & Asian & 87 & $20 \%$ & 29 & $24 \%$ & - & \\
\hline & Brazilian & 48 & $37 \%$ & 36 & $67 \%$ & $+^{4}$ & Trevilatto et al. 2003 [61] \\
\hline & Japanese & 112 & $0 \%$ & 77 & $0 \%$ & - & Komatsu et al. 2005 [62] \\
\hline & Brazilian & $155^{1}$ & $44 \%$ & 54 & $37 \%$ & - & Moreira et al. 2007 [63] \\
\hline$-190 \mathrm{C}>\mathrm{T}$ & Japanese & 112 & $0 \%$ & 77 & $0 \%$ & - & Komatsu et al. 2005 [62] \\
\hline \multirow{5}{*}{$-572 \mathrm{C}>\mathrm{G}$} & Caucasian & 148 & $6 \%$ & 107 & $20 \%$ & $++^{4}$ & Holla et al. 2004 [57] \\
\hline & Japanese & 112 & $37 \%$ & 77 & $47 \%$ & - & Komatsu et al. 2005 [62] \\
\hline & Caucasian & 326 & $10 \%$ & 144 & $8 \%$ & - & \multirow{3}{*}{ Nibali et al. 2009 [60] } \\
\hline & Afro-American & 93 & $21 \%$ & 45 & $13 \%$ & - & \\
\hline & Asian & 87 & $61 \%$ & 29 & $55 \%$ & - & \\
\hline-373 & Japanese & 112 & $12 \%$ & 77 & $21 \%$ & $+^{5}$ & Komatsu et al. 2005 [62] \\
\hline$(\mathrm{A}(\mathrm{n}) \mathrm{T}(\mathrm{m})$ & & & (A9T11) & & (A9T11) & & \\
\hline \multirow{2}{*}{$-597 \mathrm{G}>\mathrm{A}$} & Caucasian & 148 & $78 \%$ & 107 & $84 \%$ & - & Holla et al. 2004 [57] \\
\hline & Japanese & 112 & $0 \%$ & 77 & $0 \%$ & - & Komatsu et al. 2005 [62] \\
\hline & Caucasian & 326 & $14 \%$ & 144 & $22 \%$ & + & \multirow{3}{*}{ Nibali et al. 2009 [60] } \\
\hline$-1363 \mathrm{G}>\mathrm{T}$ & Afro-American & 93 & $1 \%$ & 45 & $4 \%$ & - & \\
\hline & Asian & 87 & $5 \%$ & 29 & $14 \%$ & - & \\
\hline \multirow{3}{*}{$-1480 \mathrm{C}>\mathrm{G}$} & Caucasian & 326 & $58 \%$ & 144 & $56 \%$ & - & \multirow{3}{*}{ Nibali et al. 2009 [60] } \\
\hline & Afro-American & 93 & $8 \%$ & 45 & $16 \%$ & - & \\
\hline & Asian & 87 & $19 \%$ & 29 & $24 \%$ & - & \\
\hline \multirow{3}{*}{$-6106 \mathrm{~A}>\mathrm{T}$} & Caucasian & 326 & $38 \%$ & 144 & $37 \%$ & - & \multirow{3}{*}{ Nibali et al. 2009 [60] } \\
\hline & Afro-American & 93 & $36 \%$ & 45 & $38 \%$ & - & \\
\hline & Asian & 87 & $38 \%$ & 29 & $48 \%$ & - & \\
\hline$R+48892 \mathrm{~A}>\mathrm{C}$ & Japanese & 169 & $66 \%$ & 70 & $66 \%$ & $-\left(++^{6}\right)$ & Galicia et al. 2006 [64] \\
\hline$R-183 \mathrm{G}>\mathrm{A}$ & Japanese & 169 & $76 \%$ & 70 & $74 \%$ & - & Galicia et al. 2006 [64] \\
\hline
\end{tabular}

$\mathrm{nr}=$ not reported. $-=$ association not found. $+=$ association found.

${ }^{1}$ Cases diagnosed as mixed periodontitis status.

${ }^{2}$ Only $R / R$ genotype frequency is reported and is associated with CP

${ }^{3}$ IL-6 -174, -1363, and -1480 haplotype is associated with periodontitis.

${ }^{4} \mathrm{~N} / \mathrm{N}$ genotype is associated with $\mathrm{CP}$.

${ }^{5}$ Carriage rate of the -373 A9T11 allele higher in non-CP.

${ }^{6} \mathrm{~N}$-allele is associated with CP.

ethnic populations $(<15 \%)$ (Table 5$)$. For the other TNFA polymorphisms only single studies have been reported, and positive associations with CP have been found for the -1031, -863 , and -857 loci [29].

To date there is very limited data to support associations between any of the reported TNFA gene variations and CP susceptibility. Although the SNP's TNFA -1031, -857, and -863 showed an association with CP in Japanese, these findings have not been replicated [29].
4.3. Polymorphisms in the IL4 and IL4RA Genes. Interleukine-4 (IL-4) is a pleiotropic cytokine, which is produced by the $\mathrm{T}$ helper 2 cell subpopulation and can rescue $\mathrm{B}$ lymphocytes from apoptosis and enhance their survival, thus promoting B-lymphocyte mediated immunity. IL-4 also downregulates macrophage function [149]. The gene for IL4 has been located on chromosome 5q31.1.

Gene polymorphisms studied in the IL4 gene are summarized in Table 6. An IL4 -590 promoter polymorphism 
TABLE 8: IL10 gene polymorphisms and carriage rate of the Rare $(R)$-allele in case-control studies and association with susceptibility to chronic periodontitis.

\begin{tabular}{|c|c|c|c|c|c|c|c|}
\hline \multirow[b]{2}{*}{$\begin{array}{l}\text { IL10 gene } \\
\text { polymorphism }\end{array}$} & \multirow[b]{2}{*}{$\begin{array}{l}\text { Ethnicity } \\
\text { of subjects }\end{array}$} & \multicolumn{2}{|c|}{ Patients } & \multicolumn{2}{|c|}{ Controls } & \multirow[b]{2}{*}{$\begin{array}{c}\text { Associated } \\
\text { with periodontitis }\end{array}$} & \multirow[b]{2}{*}{ Reference } \\
\hline & & $n$ & $\begin{array}{l}R \text {-allele } \\
\text { carriage }\end{array}$ & $n$ & $\begin{array}{l}R \text {-allele } \\
\text { carriage }\end{array}$ & & \\
\hline \multirow{7}{*}{$-1087(-1082) A>G$} & Caucasian & 60 & $77 \%$ & 39 & $69 \%$ & $-\left(+^{3}\right)$ & Berglundh et al. 2003 [65] \\
\hline & Caucasian & 57 & $67 \%$ & 100 & $69 \%$ & - & Brett et al. 2005 [10] \\
\hline & Caucasian & 118 & $69 \%$ & 114 & $74 \%$ & - & Babel et al. 2006 [58] \\
\hline & Caucasian & 51 & $63 \%$ & 178 & $70 \%$ & - & Tervonen et al. 2007 [13] \\
\hline & Caucasian & 27 & $81 \%$ & 34 & $70 \%$ & - & Reichert et al. 2008 [66] \\
\hline & Mixed $^{1}$ & 67 & $49 \%$ & 43 & $61 \%$ & & Scarel-Caminaga et al. 2004 [67] \\
\hline & (Caucasian) & $(48)$ & $(44 \%)$ & $(36)$ & $(61 \%)$ & $(-)$ & \\
\hline \multirow{4}{*}{$-819(-824) \mathrm{C}>\mathrm{T}$} & Caucasian & 27 & $26 \%$ & 34 & $32 \%$ & - & Reichert et al. 2008 [66] \\
\hline & Mixed $^{1}$ & 67 & $76 \%$ & 43 & $51 \%$ & + & Scarel-Caminaga et al. 2004 [67] \\
\hline & (Caucasian) & $(48)$ & $(77 \%)$ & $(36)$ & $(47 \%)$ & $(+)$ & \\
\hline & Turkish & 75 & $56 \%$ & 73 & $45 \%$ & - & Sumer et al. 2007 [68] \\
\hline$-627 C>A$ & Caucasian & 57 & $32 \%$ & 100 & $40 \%$ & - & Brett et al. 2005 [10] \\
\hline \multirow{4}{*}{$-592(-597) \mathrm{C}>\mathrm{A}$} & Mixed $^{1}$ & 67 & $72 \%$ & 43 & $51 \%$ & + & Scarel-Caminaga et al. 2004 [67] \\
\hline & (Caucasian) & $(48)$ & $(75 \%)$ & $(36)$ & $(47 \%)$ & $(+)$ & \\
\hline & Mixed $^{2}$ & 116 & $71 \%$ & 173 & $51 \%$ & + & Claudino et al. 2008 [69] \\
\hline & Turkish & 75 & $68 \%$ & 73 & $41 \%$ & + & Sumer et al. 2007 [68] \\
\hline$-590 \mathrm{C}>\mathrm{A}$ & Caucasian & 27 & $26 \%$ & 34 & $32 \%$ & - & Reichert et al. 2008 [66] \\
\hline
\end{tabular}

$\mathrm{nr}=$ not reported. $-=$ association not found. $+=$ association found.

${ }^{1} 76 \%$ of $\mathrm{CP}$ and $84 \%$ of the control population were Caucasians.

${ }^{2} 78 \%$ of CP and $79 \%$ of the control population were Caucasians.

${ }^{3} \mathrm{~N}$-allele associated with periodontitis, in particular non-smoking homozygous $N / N$ subjects.

and a 70-bp VNTR polymorphism are the most studied polymorphisms of IL4. Case-control studies have not shown any relationship between the IL4 gene polymorphims and susceptibility to $\mathrm{CP}$ in several different populations. However, a haplotype of IL4 polymorphisms (carriers of $R$-alleles in all three SNPs studied) has been associated with CP ( $17.0 \%$ in cases versus $11.0 \%$ in controls; OR 1.85) [49]. No association was found for the IL4RA polymorphims in a study on Caucasians [46].

4.4. Polymorphisms in the IL6 and IL6R Genes. Multiple roles have been identified for interleukine-6 (IL-6). It is released by different cell types and its secretion levels are determined by the cell type and the nature of the stimulus $[150,151]$. The IL6 gene was demonstrated to be localized on chromosome 7p21. IL6 polymorphisms affect the serum levels of circulating interleukin- 6 . The -174 was found to influence $I L-6$ expression and production. The $-174 R$-allele carrier individuals have decreased plasma levels of IL- 6 and present lower IL6 gene transcriptional activity when compared with $N / N$ individuals [152]. Therefore a genetically determined low IL-6 response (the $-174 R$-allele carriers) may hamper individual's defense against periodontal pathogens.

The carriage rates of the IL6 -174 R-allele varied in Caucasian populations from $44 \%$ to $54 \%$, in Brazilian populations from $37 \%$ to $67 \%$, and remarkably, the -174 as well as -190 and -597 loci were nonpolymorphic in a Japanese population (Table 7). Three out of six studies in Caucasian and one out of two studies in Brazilian populations have correlated the IL6 -174 G>C polymorphism with susceptibility to $\mathrm{CP}$. With regard to the other IL6 gene polymorphisms, the Czech study [57] suggested that the -572 polymorphism may be a protective factor to CP. Furthermore, for the other IL6 polymorphisms only single studies have been reported.

We conclude that the IL6 -174 polymorphism may be associated with CP susceptibility. However, a meta-analysis of the IL6 -174 polymorphisms did not show any association for this polymorphism with CP [148].

4.5. Polymorphisms in the IL10 Gene. Interleukine-10 (IL-10) is considered an antiinflammatory cytokine, downregulating the proinflammatory immune response of the monocytes and macrophages. However, the B lymphocyte stimulatory effect may also stimulate the production of autoantibodies [153]. As a matter of fact, auto-antibodies may play a role in periodontitis [154-156]. IL-10 is produced by monocytes, macrophages, and $\mathrm{T}$ cells and plays a role in the regulation of proinflammatory cytokines such as IL- 1 and TNF- $\alpha$.

The gene encoding for IL-10 is mapped on chromosome $1 \mathrm{q} 31-\mathrm{q} 32$, in a cluster with closely related interleukin genes, including $I L-19, I L-20$, and $I L-24$. Several promoter polymorphisms have been described in the IL10 gene: $1087(-1082),-819(-824),-627,-592(-597)$, and -590 (Table 8 ). The IL-10 $-1082,-819$, and -592 polymorphisms show strong linkage disequilibrium and form two common haplotypes. The haplotypes may be determined on basis of the IL10 -592 polymorphism [69]. The R-allele of the -592 
TABLE 9: FcyRIIa, FcyRIIIa, and FcyRIIIb gene polymorphisms and carriage rate of the Rare (R)-allele in case-control studies and association with susceptibility to chronic periodontitis.

\begin{tabular}{|c|c|c|c|c|c|c|c|}
\hline \multirow[b]{2}{*}{$\begin{array}{l}\text { FcyR gene } \\
\text { polymorphism }\end{array}$} & \multirow[b]{2}{*}{$\begin{array}{l}\text { Ethnicity } \\
\text { of subjects }\end{array}$} & \multicolumn{2}{|c|}{ Patients } & \multicolumn{2}{|c|}{ Controls } & \multirow[b]{2}{*}{$\begin{array}{c}\text { Associated } \\
\text { with periodontitis }\end{array}$} & \multirow[b]{2}{*}{ Reference } \\
\hline & & $n$ & $\begin{array}{l}R \text {-allele } \\
\text { carriage }\end{array}$ & $N$ & $\begin{array}{l}R \text {-allele } \\
\text { carriage }\end{array}$ & & \\
\hline \multirow{10}{*}{ IIa $131 \mathrm{H}>\mathrm{R}$} & Caucasian $^{1}$ & 54 & $76 \%$ & 24 & $71 \%$ & - & Colombo et al. 1998 [70] \\
\hline & Caucasian & 56 & $70 \%$ & 61 & $75 \%$ & - & Loos et al. 2003 [71] \\
\hline & Caucasian & 213 & $63 \%$ & 209 & $75 \%$ & $-\left(+^{4}\right)$ & Yamamoto et al. 2004 [72] \\
\hline & Caucasian & 132 & $72 \%$ & 72 & $74 \%$ & - & Wolf et al. 2006 [73] \\
\hline & Japanese $^{2}$ & 100 & $44 \%$ & 105 & $40 \%$ & - & Kobayashi et al. 1997 [74] \\
\hline & Japanese $^{2}$ & 83 & $46 \%$ & 104 & $39 \%$ & - & Kobayashi et al. 2000 [75] \\
\hline & Japanese & 89 & $42 \%$ & 64 & $42 \%$ & - & Kobayashi et al. 2001 [76] \\
\hline & Taiwanese & 50 & $50 \%$ & 74 & $62 \%$ & - & Chung et al. 2003 [77] \\
\hline & Japanese & $58^{3}$ & $48 \%$ & 44 & $36 \%$ & - & Kobayashi et al. 2007 [19] \\
\hline & Japanese & $100^{3}$ & $44 \%$ & 100 & $39 \%$ & - & Kobayashi et al. 2007 [20] \\
\hline \multirow{6}{*}{ IIIa $158 \mathrm{~F}>\mathrm{V}$} & Caucasian & 56 & $73 \%$ & 61 & $59 \%$ & - & Loos et al. 2003 [71] \\
\hline & Japanese $^{2}$ & 100 & $42 \%$ & 104 & $46 \%$ & - & Sugita et al. 1999 [78] \\
\hline & Japanese $^{2}$ & 83 & $43 \%$ & 104 & $46 \%$ & - & Kobayashi et al. 2000 [75] \\
\hline & Japanese & 89 & $49 \%$ & 64 & $39 \%$ & - & Kobayashi et al. 2001 [76] \\
\hline & Japanese & $58^{3}$ & $40 \%$ & 44 & $45 \%$ & - & Kobayashi et al. 2007 [19] \\
\hline & Japanese & $100^{3}$ & $45 \%$ & 100 & $45 \%$ & - & Kobayashi et al. 2007 [20] \\
\hline \multirow{11}{*}{ IIIb NA1> NA2 } & Caucasian $^{1}$ & 54 & $89 \%$ & 24 & $75 \%$ & - & Colombo et al. 1998 [70] \\
\hline & Caucasian & 56 & $88 \%$ & 61 & $92 \%$ & - & Loos et al. 2003 [71] \\
\hline & Caucasian & 132 & $84 \%$ & 72 & $89 \%$ & - & Wolf et al. 2006 [73] \\
\hline & Japanese $^{2}$ & 100 & $63 \%$ & 105 & $64 \%$ & - & Kobayashi et al. 1997 [74] \\
\hline & Japanese $^{2}$ & 83 & $64 \%$ & 104 & $64 \%$ & - & Kobayashi et al. 2000 [75] \\
\hline & Japanese & 89 & $62 \%$ & 64 & $56 \%$ & - & Kobayashi et al. 2001 [76] \\
\hline & Japanese $^{2}$ & 73 & $74 \%$ & 46 & $56 \%$ & + & Sugita et al. 2001 [79] \\
\hline & Japanese $^{2}$ & 52 & $58 \%$ & 55 & $57 \%$ & - & Yoshihara et al. 2001 [80] \\
\hline & Taiwanese & 50 & $62 \%$ & 74 & $55 \%$ & - & Chung et al. 2003 [77] \\
\hline & Japanese & $58^{3}$ & $66 \%$ & 44 & $55 \%$ & - & Kobayashi et al. 2007 [19] \\
\hline & Japanese & $100^{3}$ & $66 \%$ & 100 & $64 \%$ & - & Kobayashi et al. 2007 [20] \\
\hline
\end{tabular}

$\mathrm{nr}=$ not reported. - = association not found. $+=$ association found.

${ }^{1}$ Mainly Caucasian, actual \% of subjects of non-Caucasian heritage is not provided.

${ }^{2}$ Cases diagnosed as adult periodontitis.

${ }^{3}$ Cases diagnosed as mixed periodontitis status

${ }^{4} \mathrm{~N}$-allele is associated with periodontitis in smokers.

polymorphism has been associated with decreased synthesis of IL-10 in vitro and in vivo $[157,158]$ and may lead to altered synthesis of IL-10 in response to inflammatory stimuli [69]. IL-10 has a protective role towards periodontal tissue destruction, inhibiting both matrix metalloprteinases (MMP) and receptor activator for nuclear factor- $\kappa \mathrm{B}$ (RANK) systems $[159,160]$. Therefore the IL10 -592 R-allele carriers may be less protected against bacterial challenge.

Table 8 summarizes the case-control studies investigating genetic polymorphisms in the IL10 gene in association with CP susceptibility. The carriage rates of the IL10 -1087 Rallele vary between $44 \%$ and $81 \%$ in Caucasians. The -1087 locus has not been associated with CP susceptibility in most of Caucasian populations. However, the $-1087 \mathrm{~N}$-allele was associated with CP in Swedish Caucasians [65].

The IL10 -819 polymorphism has been correlated with $\mathrm{CP}$ in Brazilians but not in other populations [67]. Until now all three studies on the IL10 -592 polymorphism have found a higher $R$-allele carriage rate in CP patients [67-69]. The IL10 $-592 R$-allele carriage rates varied in different populations between $68 \%$ and $75 \%$ in CP patient and between $41 \%$ and $51 \%$ in controls.

One study on Japanese CP patients $(N=34)$ and controls $(N=52)$ analyzed haplotypes consisting of the IL10 $-1087,-819$, and -592 gene polymorphisms [161]. Only haplotype frequencies were reported and no separate genotype frequencies were presented. No significant differences for the carriage rates of the haplotypes of the IL10 gene were found between patients and controls. Striking was the complete absence of the $N$-allele carriage at position -1087 among the Japanese, in contrast to Caucasians (Table 8), where the $1087 \mathrm{~N}$-allele is the most occurring variant $[65,161]$.

For conclusion, IL10 -592 R-allele carriage rates have been associated with $\mathrm{CP}$ susceptibility and the results have 
TABLE 10: The vitamin D receptor (VDR) gene polymorphisms and carriage rate of the Rare $(R)$-allele in case-control studies and association with susceptibility to chronic periodontitis.

\begin{tabular}{|c|c|c|c|c|c|c|c|}
\hline \multirow[b]{2}{*}{$\begin{array}{l}\text { VDR gene } \\
\text { polymorphism }\end{array}$} & \multirow[b]{2}{*}{$\begin{array}{l}\text { Ethnicity } \\
\text { of subjects }\end{array}$} & \multicolumn{2}{|c|}{ Patients } & \multicolumn{2}{|c|}{ Controls } & \multirow[b]{2}{*}{$\begin{array}{l}\text { Associated } \\
\text { with periodontitis }\end{array}$} & \multirow[b]{2}{*}{ Reference } \\
\hline & & $n$ & $\begin{array}{l}R \text {-allele } \\
\text { carriage }\end{array}$ & $n$ & $\begin{array}{l}R \text {-allele } \\
\text { carriage }\end{array}$ & & \\
\hline \multirow{6}{*}{$\operatorname{Taq} 1 \mathrm{~T}>\mathrm{C}$} & Caucasian & 57 & $49 \%$ & 100 & $78 \%$ & + & Brett et al. 2005 [10] \\
\hline & Caucasian & 58 & $53 \%$ & 140 & $63 \%$ & $+^{3}$ & Nibali et al. 2008 [81] \\
\hline & Chinese $^{1}$ & 24 & $4 \%$ & 39 & $5 \%$ & - & Sun et al. 2002 [82] \\
\hline & Japanese & 74 & $11 \%$ & 94 & $23 \%$ & $+^{4}$ & Tachi et al. 2003 [83] \\
\hline & Brazilian & 69 & $67 \%$ & 44 & $45 \%$ & $+\left(+^{5}\right)$ & de Brito et al. 2004 [84] \\
\hline & Turkish & 72 & $50 \%$ & 102 & $42 \%$ & $-\left(+^{6}\right)$ & Gunes et al. 2008 [85] \\
\hline \multirow{4}{*}{ Bsm $1 \mathrm{~A}>\mathrm{G}$} & Japanese $^{1}$ & 52 & $21 \%$ & 55 & $20 \%$ & - & Yoshihara et al. 2001 [80] \\
\hline & Japanese & 17 & $23 \%$ & $80^{2}$ & $19 \%$ & $-\left(+^{7}\right)$ & Naito et al. 2007 [86] \\
\hline & Brazilian & 69 & $86 \%$ & 44 & $82 \%$ & $-\left(+^{5}\right)$ & de Brito Junior et al. 2004 [84] \\
\hline & Turkish & 72 & $86 \%$ & 102 & $91 \%$ & $-\left(+^{6}\right)$ & Gunes et al. 2008 [85] \\
\hline \multirow{2}{*}{ Fok1 A>G } & Japanese & 74 & $63 \%$ & 94 & $54 \%$ & - & Tachi et al. 2003 [83] \\
\hline & Japanese & 17 & $47 \%$ & $80^{6}$ & $69 \%$ & $-\left(+^{7}\right)$ & Naito et al. 2007 [86] \\
\hline \multirow{2}{*}{ Apal G>T } & Japanese & 17 & $30 \%$ & $80^{6}$ & $53 \%$ & $-\left(+^{7}\right)$ & Naito et al. 2007 [86] \\
\hline & Turkish & 72 & $54 \%$ & 102 & $61 \%$ & $-\left(+^{6}\right)$ & Gunes et al. 2008 [85] \\
\hline
\end{tabular}

$\mathrm{nr}=$ not reported. - = association not found. $+=$ association found.

${ }^{1}$ Cases diagnosed as adult periodontitis.

${ }^{2}$ Control group consists of patients without severe periodontitis.

${ }^{3}$ The $N / N$ genotype is associated with periodontitis in smokers.

${ }^{4}$ The $N$-allele is associated with periodontitis, also when adjusted for smoking and diabetes.

${ }^{5}$ The Bsm1/Taq1 N/N haplotype is associated with periodontitis.

${ }^{6}$ The Apa1/Bsm1/Taq1 haplotype is associated with severe periodontitis.

${ }^{7}$ The Apa1/Bsm1/Fok1 haplotype is associated with severe periodontitis.

been replicated [67-69]. Therefore we conclude that the IL10 -592 polymorphism may be a genetic marker for CP susceptibility.

4.6. Polymorphisms in the FcyR Gene. Leukocyte receptors for the constant (or Fc-) part of immunoglobulin (FCR) link cellular and humoral parts of the immune system, which are considered essential for the host defense against bacteria.

$\mathrm{Fc} \gamma \mathrm{Rs}$ are found on a wide variety of immune cells in the periodontal tissues [162]. Fc $\gamma$ Rs are likely to play a role in the pathogenesis of periodontitis [163]. Microorganisms and bacterial antigens, opsonized with antibody, can be phagocytosed via $\mathrm{Fc} \gamma \mathrm{R}$ on neutrophils or internalized via $\mathrm{Fc} \gamma \mathrm{R}$ by a variety of antigen presenting cells, including monocytes, macrophages, and $\mathrm{B}$ cells. $\mathrm{T}$ cells and natural killer cells may become activated, when IgGopsonized bacteria are bound to these cells via Fc $\gamma \mathrm{R}$; a variety of cytokines and chemokines may also be released [164].

The F $\gamma$ R genes are found on chromosome 1 and encode 3 main receptor classes: Fc $\gamma$ RI (CD64), Fc $\gamma$ RII (CD32), and Fc $\gamma$ RIII (CD16). These classes are further subdivided into subclasses: Fc $\gamma$ RIa and b, Fc $\gamma$ RIIa, b, and c, and Fc $\gamma$ RIIIa and b. Structural and functional differences in Fc $\gamma$ RIIa, IIIa, and $\mathrm{b}$ have been described [164, 165].

The studies that have investigated the FcyRIIa, FcyRIIIa, and $F c \gamma R I I I b$ polymorphisms in relation to periodontitis are summarized in Table 9. Several studies have investigated the FcyRIIa polymorphisms in relation to CP. In Caucasians, the carriage rate of the FcyRIIa R-allele is relatively high: $63 \%-76 \%$ [70-73] and in Asian populations the carriage rate is lower: $36 \%-62 \%$ (Table 9). In general, the Fc $\gamma$ RIIa polymorphisms are not associated with CP. However, Yamamota et al. [72] observed a decreased prevalence of the Fc $\gamma$ RIIa $R$-allele among Caucasian CP patients and controls in a large case-control study. Homozygosity for the $N$-allele was significantly more prevalent in smoking $\mathrm{CP}$ patients [72].

A lower $R$-allele carriage rate of the Fc $\gamma$ RIIIa gene is seen in Japanese in comparison to the Caucasians. In a Japanese population it was found that the FcyRIIIa R-allele was overrepresented in patients with periodontal disease recurrence [78]. In contrast, another Japanese study showed that the Fc $\gamma$ RIIIa $\mathrm{N}$-allele was overrepresented in patients with severe periodontitis versus subjects with moderate disease [76]. But none of the studies have associated the Fc $\gamma$ RIIIa polymorphisms with CP susceptibility. It is apparent that there are conflicting results and comparisons between the different studies are difficult as the prevalences of $F c \gamma R$ genotypes differ among subjects of different ethnic background.

The carriage rate of the FcyRIIIb R-allele in Caucasians was relatively high $(>75 \%)$ and in Asians some what lower (55\%-74\%). In Caucasians no associations have been found between the $F c \gamma R I I I b R$-allele carriage and CP susceptibility. However, in one Japanese study the $R$-allele carriage has been associated with CP susceptibility [79]. Two studies of Kobayashi et al. [74, 76] have shown an association with CP disease recurrence and severity in combination with FcyRIIIa $N$-allele. 
TABLE 11: CD14, TLR2, and TLR4 gene polymorphisms and carriage rate of the Rare $(R)$-allele in case-control studies and association with susceptibility to chronic periodontitis.

\begin{tabular}{|c|c|c|c|c|c|c|c|}
\hline & \multirow[b]{2}{*}{$\begin{array}{l}\text { Ethnicity } \\
\text { of subjects }\end{array}$} & \multicolumn{2}{|c|}{ Patients } & \multicolumn{2}{|c|}{ Controls } & \multirow[b]{2}{*}{$\begin{array}{c}\text { Associated } \\
\text { with periodontitis }\end{array}$} & \multirow[b]{2}{*}{ Reference } \\
\hline & & $n$ & $\begin{array}{l}R \text {-allele } \\
\text { carriage }\end{array}$ & $n$ & $\begin{array}{l}R \text {-allele } \\
\text { carriage }\end{array}$ & & \\
\hline \multirow{10}{*}{$C D 14-260^{1} \mathrm{C}>\mathrm{T}$} & Caucasian & 135 & $74 \%$ & 207 & $70 \%$ & - & Holla et al. 2002 [87] \\
\hline & Caucasians & 70 & $66 \%$ & 75 & $76 \%$ & $-\left(++^{3}\right)$ & Folwaczny et al. 2004 [88] \\
\hline & Caucasian & 60 & $67 \%$ & 39 & $77 \%$ & $+^{4}$ & Donati et al. 2005 [46] \\
\hline & Caucasian $^{2}$ & 100 & $74 \%$ & 99 & $71 \%$ & $+^{5}$ & Laine et al. 2005 [89] \\
\hline & Caucasian & 95 & $75 \%$ & 94 & $77 \%$ & - & James et al. 2007 [90] \\
\hline & Caucasian & 51 & $47 \%$ & 178 & $57 \%$ & $-\left(++^{6}\right)$ & Tervonen et al. 2007 [13] \\
\hline & Caucasian & 60 & $67 \%$ & 80 & $64 \%$ & - & Schulz et al. 2008 [91] \\
\hline & Caucasian $^{2}$ & 72 & $76 \%$ & 35 & $80 \%$ & - & Nicu et al. 2009 [92] \\
\hline & Non-Caucasian ${ }^{2}$ & 33 & $64 \%$ & 22 & $86 \%$ & - & \\
\hline & Japanese & 163 & $75 \%$ & 104 & $82 \%$ & $-\left(+^{7}\right)$ & Yamazaki et al. 2003 [93] \\
\hline \multirow{2}{*}{ CD14-1359 } & Caucasian & 135 & $43 \%$ & 207 & $42 \%$ & - & Holla et al. 2002 [87] \\
\hline & Caucasian & 95 & $38 \%$ & 94 & $35 \%$ & - & James et al. 2007 [90] \\
\hline \multirow{4}{*}{ TLR2 Arg677Trp } & Caucasian & 122 & $0 \%$ & 122 & $0 \%$ & - & Folwaczny et al. 2004 [88] \\
\hline & Caucasian & 83 & $0 \%$ & 106 & $0 \%$ & - & Berdeli et al. 2007 [94] \\
\hline & Japanese & 97 & $0 \%$ & 100 & $0 \%$ & - & Fukusaki et al. 2007 [95] \\
\hline & Chinese & 50 & $100 \%$ & 100 & $100 \%$ & - & Zhu et al. 2008 [96] \\
\hline \multirow{4}{*}{ TLR2 Arg753Gln } & Caucasian & 122 & $3 \%$ & 122 & $4 \%$ & - & Folwaczny et al. 2004 [88] \\
\hline & Caucasian & 83 & $13 \%$ & 106 & $13 \%$ & - & Berdeli et al. 2007 [94] \\
\hline & Japanese & 97 & $0 \%$ & 100 & $0 \%$ & - & Fukusaki et al. 2007 [95] \\
\hline & Chinese & 50 & $0 \%$ & 100 & $6 \%$ & - & Zhu et al. 2008 [96] \\
\hline TLR2 - 183 & Japanese & 97 & $0 \%$ & 100 & $1 \%$ & - & Fukusaki et al. 2007 [95] \\
\hline TLR2 -148 & Japanese & 97 & $0 \%$ & 100 & $1 \%$ & - & Fukusaki et al. 2007 [95] \\
\hline TLR2 - 146 & Japanese & 97 & $0 \%$ & 100 & $1 \%$ & - & Fukusaki et al. 2007 [95] \\
\hline$T L R 2+1350$ & Japanese & 97 & $40 \%$ & 100 & $28 \%$ & - & Fukusaki et al. 2007 [95] \\
\hline TLR2 +2343 & Japanese & 97 & $0 \%$ & 100 & $3 \%$ & - & Fukusaki et al. 2007 [95] \\
\hline \multirow{10}{*}{ TLR4 Asp299Gly } & Caucasian & 122 & $4 \%$ & 122 & $3 \%$ & - & Folwaczny et al. 2004 [88] \\
\hline & Caucasian & 57 & $11 \%$ & 100 & $7 \%$ & - & Brett et al. 2005 [10] \\
\hline & Caucasian $^{2}$ & 100 & $10 \%$ & 99 & $9 \%$ & - & Laine et al. 2005 [89] \\
\hline & Caucasian & 83 & $5 \%$ & 106 & $6 \%$ & - & Berdeli et al. 2007 [94] \\
\hline & Caucasian & 171 & $14 \%$ & 218 & $11 \%$ & - & Holla et al. 2007 [97] \\
\hline & Caucasian & 95 & $19 \%$ & 94 & $17 \%$ & - & James et al. 2007 [90] \\
\hline & Caucasian & 51 & $25 \%$ & 178 & $20 \%$ & - & Tervonen et al. 2007 [13] \\
\hline & Caucasian & 60 & $13 \%$ & 80 & $9 \%$ & - & Schulz et al. 2008 [91] \\
\hline & Japanese & 97 & $0 \%$ & 100 & $0 \%$ & - & Fukusaki et al. 2007 [95] \\
\hline & Chinese & 50 & $0 \%$ & 100 & $0 \%$ & - & Zhu et al. 2008 [96] \\
\hline \multirow{9}{*}{ TLR4 Thr399Ile } & Caucasian & 122 & $4 \%$ & 122 & $4 \%$ & - & Folwaczny et al. 2004 [88] \\
\hline & Caucasian & 57 & $7 \%$ & 100 & $18 \%$ & - & Brett et al. 2005 [10] \\
\hline & Caucasian $^{2}$ & 100 & $10 \%$ & 99 & $9 \%$ & - & Laine et al. 2005 [89] \\
\hline & Caucasian & 83 & $4 \%$ & 106 & $5 \%$ & - & Berdeli et al. 2007 [94] \\
\hline & Caucasian & 171 & $14 \%$ & 218 & $10 \%$ & - & Holla et al. 2007 [97] \\
\hline & Caucasian & 95 & $22 \%$ & 94 & $20 \%$ & - & James et al. 2007 [90] \\
\hline & Caucasian & 60 & $13 \%$ & 80 & $9 \%$ & - & Schulz et al. 2008 [91] \\
\hline & Japanese & 97 & $0 \%$ & 100 & $0 \%$ & - & Fukusaki et al. 2007 [95] \\
\hline & Chinese & 50 & $0 \%$ & 100 & $0 \%$ & - & Zhu et al. 2008 [96] \\
\hline
\end{tabular}


TABLe 11: Continued.

\begin{tabular}{|c|c|c|c|c|c|c|c|}
\hline & \multicolumn{4}{|c|}{ Patients } & \multicolumn{3}{|c|}{ Controls } \\
\hline & $\begin{array}{l}\text { Ethnicity } \\
\text { of subjects }\end{array}$ & $n$ & $\begin{array}{l}R \text {-allele } \\
\text { carriage }\end{array}$ & $n$ & $\begin{array}{l}R \text {-allele } \\
\text { carriage }\end{array}$ & $\begin{array}{c}\text { Associated } \\
\text { with periodontitis }\end{array}$ & Reference \\
\hline TLR4 +3528 & Japanese & 97 & $0 \%$ & 100 & $2 \%$ & - & Fukusaki et al. 2007 [95] \\
\hline$T L R 4+3525$ & Japanese & 97 & $26 \%$ & 100 & $29 \%$ & + & Fukusaki et al. 2007 [95] \\
\hline TLR $4+4022$ & Japanese & 97 & $0 \%$ & 100 & $1 \%$ & - & Fukusaki et al. 2007 [95] \\
\hline TLR4 +4529 & Japanese & 97 & $2 \%$ & 100 & $1 \%$ & - & Fukusaki et al. 2007 [95] \\
\hline
\end{tabular}

$\mathrm{nr}=$ not reported. $-=$ association not found. $+=$ association found .

${ }^{1}$ Also refered as -159 .

${ }^{2}$ Cases diagnosed as adult periodontitis.

${ }^{3}$ The $N$-allele is associated with periodontitis in women.

${ }^{4}$ The $N$-allele is associated with CP.

${ }^{5}$ The $R / R$ genotype is associated with CP also after correcting for age, gender, smoking, and presence A. actinomytemcomitans and P. gingivalis.

${ }^{6}$ The $R$-allele is associated with disease severity.

${ }^{7}$ The $R$-allele associated with early disease development.

Initially, polymorphisms in the $F c y R$ genes were suggested to play a role in periodontitis [166]; however in the present review on the susceptibility to $\mathrm{CP}$, only one study out of ten found CP to be associated with FcyRIIa polymorphism in smokers [72], and one out of nine studies with FcyRIIIb [79]. Therefore we conclude that the reported $F c \gamma R$ gene polymorphisms are not associated with CP susceptibility. However, to date no large-scale epidemiological investigations are available, and subsequently no clear and convincing data is presented to assign the $F c \gamma R$ gene polymorphisms as risk factors for $\mathrm{CP}$.

4.7. Polymorphisms in the VDR Gene. Vitamin D plays a role in bone metabolism. Since alveolar bone resoption is a major characteristic of periodontal disease, it is plausible that mediators of bone metabolism like the vitamin $\mathrm{D}$ receptor $(V D R)$ and its' genetic polymorphisms play a role in $\mathrm{CP}$ susceptibility. In addition to mediating bone homeostasis, vitamin $\mathrm{D}$ and its receptor play a role in phagocytosis by monocytes and affect monocyte differentiation [167].

The human VDR gene is localized on chromosome $12 \mathrm{q} 12-\mathrm{q} 14$. Genetic polymorphisms in the VDR gene have also been associated with infectious diseases, in particular tuberculosis $[168,169]$. The mechanisms by which VDR gene polymorphisms may influence $\mathrm{CP}$ susceptibility have not been clarified yet. The Taq1, Bsm1, and Apa1 polymorphisms do not change the translated protein whereas the Fokl polymorphism may be functional creating an additional start codon (ACG to ATG) [170].

Several studies have identified VDR polymorphisms in relation to CP at RFLP positions Taq1, Bsm1, Fok1, and Apa1 (Table 10) [10, 80-86]. Most of the studies on the SNPs of the $V D R$ gene have found associations with $\mathrm{CP}$, however not always unconditionally (Table 10).

The carriage rates of the VDR Taq1 $R$-allele range between $42 \%$ and $78 \%$ across different ethnic populations, except in Asian populations where lower rates (4\%-23\%) have been reported (Table 10). Not the Taq1 R-allele but the $N$-allele has been associated with $\mathrm{CP}$ susceptibility in several studies (Table 10). Another VDR polymorphism (Bsm1) showed no association with CP as a single SNP but in different haplotype combinations with the other $V D R$ polymorphisms [84-86].

The VDR gene is an interesting candidate gene for its association with periodontitis, because it affects both bone metabolism and immune functions. The VDR Taq1 SNP may be associated with CP susceptibility as a single polymorphism or in combination with other VDR gene polymorphisms.

4.8. Polymorphisms in the Pattern Recognition Receptor Genes. The innate immune system recognizes pathogen-associated molecular patterns (PAMPs) that are expressed on microorganisms, but not on host cells. Extra- and intracellular receptors like CD14, CARD15, and Toll-like receptors (TLRs) recognize PAMPs of Gram-positive and Gram-negative bacteria and mediate the production of cytokines necessary for further development of effective immunity. Both TLR2 and TLR4 use CD14 as a coreceptor.

4.8.1. Polymorphisms in the CD14 Gene. The gene for CD14 is located on chromosome 5q21-q23. The CD14 -260 (159) promotor polymorphism is located upstream from the major transcriptional site, affecting the transcriptional activity and CD14 density [171]. Individuals homozygous for the $R$-allele have increased serum levels of soluble (s) CD14 and an increased density of CD14 in monocytes [171]. The CD14 -260 $R$-allele has previously been associated with increased risk of myocardial infarction [171] and Crohn's disease [172]. Given that the CD14-260 N-allele leads to a reduced expression of the CD14 receptor it is assumed that individuals carrying the $N$-allele may be more susceptible to $\mathrm{CP}$ since they are less protected by the CD14 receptor [173].

Carriage rate of the CD14-260 R-allele varies in different ethinic populations from $47 \%$ to $82 \%$. Eight studies have investigated the CD14 -260 polymorphism in Caucasian CP subjects (Table 11), but the results are conflicting. Two studies found an association with the $\mathrm{N}$-allele and another study with the $R$-allele whereas five studies did not find any association with the CP susceptibility [87, 93].

Results for another polymorphism (position -1359) in the $C D 14$ gene have also been reported $[87,90]$; no 
TABle 12: Miscellaneous candidate genes and the corresponding encoded proteins studied in relation to susceptibility to chronic periodontitis and reported association.

\begin{tabular}{|c|c|c|c|}
\hline $\begin{array}{l}\text { Polymorphism } \\
\text { in gene }\end{array}$ & Coded protein & Reference & $\begin{array}{l}\text { Associated } \\
\text { with periodontitis }\end{array}$ \\
\hline ACE & Angiotensin-converting enzyme & Holla et al. 2001 [98] & $-\left(++^{1}\right)$ \\
\hline$B P I$ & Bactericidal/permeability-increasing protein & Glas et al. 2006 [99] & - \\
\hline \multirow{2}{*}{ CARD15 (NOD2) } & \multirow{2}{*}{ Caspase recruitment domain-15 } & Folwaczny et al. 2004 [100] & - \\
\hline & & Laine et al. 2004 [101] & - \\
\hline \multirow{3}{*}{ CCR5 } & \multirow{3}{*}{ Chemokine receptor-5 } & Folwaczny et al. 2003 [102] & - \\
\hline & & Wohlfahrt et al. 2006 [59] & - \\
\hline & & Savarrio et al. 2007 [103] & - \\
\hline COL1A1 & Type 1 collagen & Sakellari et al. 2006 [12] & - \\
\hline \multirow{2}{*}{$C O X-2$} & \multirow{2}{*}{ Cyclooxygenase-2 } & Ho et al. $2008[104]$ & + \\
\hline & & Xie et al. 2009 [105] & + \\
\hline CTLA-4 & Cytotoxic T-lymphocyte antigen- 4 & Wohlfahrt et al. 2006 [59] & - \\
\hline$D E F B 1$ & Human $\beta$ defensin $\tilde{\beta} 1$ & Wohlfahrt et al. 2006 [59] & - \\
\hline eNOS & Endothelial nitric oxide synthase & Berdeli et al. 2006 [106] & + \\
\hline$E R 2$ & Estrogen receptor-2 & Zhang et al. 2004 [107] & - \\
\hline E-selectin & E-selectin & Houshmand et al. 2009 [108] & + \\
\hline ET1 & Endothelin-1 & Holla et al. 2001 [98] & - \\
\hline FasL & Fas ligand & Wohlfahrt et al. 2006 [59] & - \\
\hline$F B R$ & Fibrinogen & Sahingur et al. 2003 [109] & $+^{2}$ \\
\hline \multirow{2}{*}{ FcyRIIb } & \multirow{2}{*}{ Fc $\gamma$ receptor IIb } & Yasuda et al. 2003 [110] & + \\
\hline & & Kobayashi et al. 2007 [19] & + \\
\hline GSTM1 & Glutathione-S-transferase M1 & Concolino et al. 2007 [111] & + \\
\hline GSTT1 & Glutathione-S-transferase T1 & Concolino et al. 2007 [111] & - \\
\hline$I C A M-1$ & Intercellular adhesion molecule-1 & Wohlfahrt et al. 2006 [59] & - \\
\hline ICOS & Inducible costimulator & Wohlfahrt et al. 2006 [59] & - \\
\hline \multirow{2}{*}{$I F N G$} & \multirow{2}{*}{ Interferon $\gamma$} & Hooshmand et al. 2008 [52] & - \\
\hline & & Reichert et al. 2008 [112] & - \\
\hline \multirow{2}{*}{ IFNGR1 } & \multirow{2}{*}{ Interferon $\gamma$ receptor-1 } & Fraser et al. 2003 [113] & $-\left(+^{3}\right)$ \\
\hline & & Babel et al. 2006 [58] & - \\
\hline IL2 & Interleukin-2 & Scarel-Caminaga et al. 2002 [114] & - \\
\hline \multirow{2}{*}{$\begin{array}{l}\text { IL12 } \\
\text { IL12RB2 }\end{array}$} & \multirow{2}{*}{ Interleukin-12 } & Reichert et al. 2008 [112] & - \\
\hline & & Takeuchi-Hatanaka et al. 2008 [115] & - \\
\hline IL16 & Interleukin-16 & Folwaczny et al. 2005 [116] & - \\
\hline IL18 & Interleukin-18 & Folwaczny et al. 2005 [117] & - \\
\hline IL24 & Interleukin-24 & Savarrio et al. 2007 [103] & - \\
\hline Lactoferrin & Lactoferrin & Wu et al. 2009 [118] & - \\
\hline L-selectin & L-selectin & Houshmand et al. 2009 [108] & - \\
\hline \multirow{2}{*}{ LTA } & \multirow{2}{*}{ Lymphotoxin- $\alpha$} & Holla et al. 2001 [98] & + \\
\hline & & Fassmann et al. 2003 [44] & $-\left(++^{4}\right)$ \\
\hline \multirow{2}{*}{$M B L$} & \multirow{2}{*}{ Mannose binding lectin } & Louropoulou et al. 2008 [119] & - \\
\hline & & Tsutsumi et al. 2009 [120] & - \\
\hline \multirow{7}{*}{$M M P 1$} & \multirow{7}{*}{ Matrix metalloproteinase-1 } & de Souza et al. 2003 [121] & $-\left(+^{5}\right)$ \\
\hline & & Holla et al. 2004 [122] & - \\
\hline & & Itagaki et al. 2004 [123] & - \\
\hline & & Astolfi et al. 2006 [124] & - \\
\hline & & Cao et al. 2006 [125] & + \\
\hline & & Pirhan et al. 2008 [126] & + \\
\hline & & Ustun et al. 2008 [127] & \\
\hline
\end{tabular}


TABLE 12: Continued.

\begin{tabular}{|c|c|c|c|}
\hline $\begin{array}{l}\text { Polymorphism } \\
\text { in gene }\end{array}$ & Coded protein & Reference & $\begin{array}{c}\text { Associated } \\
\text { with periodontitis }\end{array}$ \\
\hline \multirow{2}{*}{ MMP2 } & \multirow{2}{*}{ Matrix metalloproteinase-1 (gelatinase A) } & Holla et al. 2005 [128] & - \\
\hline & & Gurkan et al. 2008 [129] & - \\
\hline \multirow{2}{*}{ MMP3 } & \multirow{2}{*}{ Matrix metalloproteinase- 3} & Itagaki et al. 2004 [123] & - \\
\hline & & Astolfi et al. 2006 [124] & + \\
\hline \multirow{4}{*}{ MMP9 } & \multirow{4}{*}{ Matrix metalloproteinase- 9} & de Souza et al. 2005 [130] & - \\
\hline & & Holla et al. 2006 [131] & - \\
\hline & & Keles et al. 2006 [132] & + \\
\hline & & Gurkan et al. 2008 [129] & - \\
\hline MMP12 & Matrix metalloproteinase-12 & Gurkan et al. 2008 [129] & - \\
\hline$M P O$ & Myeloperoxidase & Meisel et al. 2002 [133] & $-\left(++^{6}\right)$ \\
\hline \multirow{2}{*}{ NAT2 } & \multirow{2}{*}{$\mathrm{N}$-acetyltransferase- 2} & Meisel et al. 2000 [134] & + \\
\hline & & Kocher et al. 2002 [135] & - \\
\hline \multirow{4}{*}{$O P G$} & \multirow{4}{*}{ Osteoprotegerin } & Wohlfahrt et al. 2006 [59] & - \\
\hline & & Wagner et al. 2007 [14] & - \\
\hline & & Baioni et al. 2008 [136] & - \\
\hline & & Park et al. 2008 [137] & $-\left(+^{7}\right)$ \\
\hline OPN & Osteopontin & Wohlfahrt et al. 2006 [59] & - \\
\hline \multirow{2}{*}{ PAI1 } & \multirow{2}{*}{ Plasminogen-activator-inhibitor-1 } & Holla et al. 2002 [138] & + \\
\hline & & Gurkan et al. 2007 [139] & - \\
\hline RAGE & Receptor for advanced glycation end products & Holla et al. $2001[140]$ & + \\
\hline RANTES & Regelated on activation, normal $\mathrm{T}$ cells expressed and secreted & Savarrio et al. 2007 [103] & - \\
\hline S100A8 & Calprotectin & Li et al. 2007 [141] & $+^{8}$ \\
\hline SFTPD & Surfactant protein D & Glas et al. 2008 [142] & - \\
\hline \multirow{4}{*}{ TGFB1 } & \multirow{4}{*}{ Transforming growth factor- $\beta_{1}$} & Holla et al. 2002 [143] & - \\
\hline & & de Souza et al. 2003 [144] & - \\
\hline & & Atilla et al. 2006 [145] & + \\
\hline & & Babel et al. 2006 [58] & $+{ }^{9}$ \\
\hline TIMP2 & Tissue inhibitor of matrix metalloproteinase & de Souza et al. 2005 [130] & - \\
\hline TNFR2 & Tumor necrosis factor receptor- 2 & Shimada et al. 2004 [146] & + \\
\hline$t-P A$ & Tissue plasminogen-activator & Gurkan et al. 2007 [139] & - \\
\hline
\end{tabular}

$-=$ association not found. $+=$ association found.

${ }^{1}$ in combination with LTA.

${ }^{2} R$-allele associated with higher serum fibrinogen.

${ }^{3} R$-allele in combination with smoking.

${ }^{4} \mathrm{~N}$-allele protective in combination with TNFA-308.

${ }^{5} R$-allele associated in non-smokers.

${ }^{6} R$-allele protective for females.

${ }^{7} 950 \mathrm{~T}$ and $1181 \mathrm{G}$ haplotype is associated with CP.

${ }^{8} \mathrm{~N}$-allele of rs3795391and rs3806232 is associated with CP in Chinese males.

${ }^{9} R$-allele of codon 25 associated with CP.

association with $\mathrm{CP}$ susceptibility was found. However a higher frequency of the $N$-allele and the $N / N$ genotype of the CD14-1359 polymorphism was found in patients with severe periodontal disease than in patients with moderate periodontitis (Table 11) [87].

We conclude that the CD14-260 polymorphism may be associated with CP susceptibility.

4.8.2. Polymorphisms in the TLR2 and TLR4 Genes. TLR 2 and TLR4 genes map on chromosome $4 \mathrm{q} 32$ and $9 \mathrm{q} 32$ q33, respectively. TLR2 Arg677Trp and Arg753Gln gene polymorphisms have been reported to change the ability of TLR2 to mediate a response to bacterial components [174]. Two common cosegregating missense polymorphisms of TLR4, Asp299Gly and Thr399Ile, affect the extracellular domain of the TLR4 protein, leading to an attenuated efficacy of LPS signalling and a reduced capacity to elicit inflammation [175]. The TLR4 Asp299Gly gene polymorphism has been correlated with sepsis and infections caused by Gram-negative bacteria [176]. The above named TLR polymorphisms have been studied by several groups in association with periodontitis (Table 11) [10, 13, 89-91, 94$97,177]$. However, in spite of the perceived importance of these functional TLR polymorphisms, no relation with $\mathrm{CP}$ 
has been observed. Nine SNPs in the TLR 2 and TLR4 genes have been studied by Fukusaki et al. [95] in a Japanese population, and TLR $4+3725$ polymorphism was found to be associated with CP.

Interestingly, the TLR2 677 loci was not polymorphic in Caucasian and Japanese populations [94, 95, 177], but the heterozygotic genotype was found in $100 \%$ of the Han Chinese [96]. The TLR2 753 and the TLR4 polymorphisms were not or in very low percentage polymorphic in Asian populations. In Caucasian populations the TLR4 299 and 399 carriage rates of the $R$-allele ranged between $4 \%$ and $25 \%$ (Table 11).

Although the pattern recognition receptor genes seem good candidates for their association with periodontitis, investigations have not yielded any strong indications that they might be associated with $\mathrm{CP}$ susceptibility.

4.9. Polymorphisms in Miscellaneous Genes. Miscellaneous candidate gene polymorphisms that have been studied in relation to $\mathrm{CP}$ are listed in Table 12. These are not discussed in detail as the other candidate genes above, since mainly negative results and/or too few studies are published for a meaningful analysis. However, Table 12 illustrates the variety of candidate genes and the difficulty in interpreting results; if positive results are reported, these are often in subgroups or conditionally.

\section{Discussion and Conclusions}

Case-control association study design is considered a powerful method in detecting high frequently occurring, smalleffect gene polymorphisms. However, this study design is susceptible to a variety of potential methodological flaws. An important concern is selection of case and control subjects because it has a great impact on study outcome. To be able to detect genetic polymorphisms playing a role in disease predisposition, strict phenotype classification should be employed during the selection procedure of the study subjects. Importantly, the clinical symptoms like deepening of the periodontal pocket, loss of attachment, and alveolar bone loss are same in different forms of periodontal diseases. Also definition of control subjects may vary in different studies. Some reports characterize their control subjects as healthy, while others describe their control subjects as gingivitis patients or population controls. Inaccuracy in disease classification of CP makes the case-control studies and replication of the studies difficult.

Another possible bias in case-control studies is the diversity of ethnic background of study cohorts. Since genotype and allele frequencies may differ between different ethnic populations [178], case and control subjects should be selected on the basis of the same ethnic background. A genetic risk factor for disease susceptibility in one population may not be a risk factor in the other population.

From the current review, it became clear that a fairly large number of studies on CP susceptibility are limited by their sample size and power. Subsequently, no gene polymorphism has, as yet, been definitely shown to be a risk factor for CP susceptibility. Small sample size studies are greatly underpowered, since most associations refer to small odds ratio's (range 1.1-1.5) and greatly contribute to the risk for false positive or negative results [179]. For instance, approximately 2000 cases and 2000 controls would be required to provide $80 \%$ power to detect an odds ratio of 1.5 at a $R$-allele frequency of 0.1 and at an appropriate level of significance [180]. However many disease susceptibility polymorphisms will confer an odds ratio less than 1.5 , requiring larger patient cohorts. Sufficient number of cases and controls must be recruited in order to minimize the risk of identifying false positive associations that are due to chance alone or, conversely, of failing to detect a true association between a polymorphism and a disease (false negatives).

Typical for the multifactorial and polygenic complex diseases is that each genetic polymorphism has generally only a modest effect, and that the interaction of genes and their polymorphisms with each other (gene-gene interaction) and with environmental factors (gene-environment interaction) potentially has influence on the observed phenotype. Therefore, multivariate analyses should be included to generate odds ratios taking into account next to age and genderestablished risk factors like smoking, microbial factors, and eventually interaction with other gene polymorphisms.

In case-control studies selection of candidate genes and their polymorphisms is based on a priori knowledge of disease pathogenesis and phenotypes. Consequently, one of the greatest challenges in candidate gene studies remains the intelligent selection of candidate genes and their polymorphisms. However the amount of knowledge, to date, is enormous and effective computer-based methods may be helpful for deciding a priori which genes, polymorphisms, and combinations (haplotypes) have the greatest chance of influencing disease susceptibility [181, 182]. Most genetic research on $\mathrm{CP}$ susceptibility has focused sofar on gene polymorphisms that play a role in the recognition and clearance of bacteria by the immune system, tissue destructive processes, or metabolic mechanisms.

Meta-analyses may be a helpful approach in rationalizing the results from several small and conflicting studies. Once a considerable amount of studies are available, metaanalyses may be performed to pool data from different studies and determine allele frequencies in the different populations. However, meta-analyses may still have inherent problems such as including individual studies that employ widely different phenotype criteria, and publication bias. Previously, it has been demonstrated that molecular genetic research is sensitive to "negative" publication bias [183]. Evidently, further studies on gene polymorphisms in $\mathrm{CP}$ susceptibility are needed employing large amounts of individuals. Definite conclusions can be drawn on basis of multiple, large-scale studies. Consortia and collaborative studies may help to defeat the limitations of the individual studies.

In conclusion, research on genetic polymorphisms in the recent years has had limited success in unravelling significant and reproducible genetic factors for susceptibility to CP. Taken together the data published so far on gene polymorphisms in $\mathrm{CP}$, we conclude that at this point there 
is a relatively large variation among the various studies for the $R$-allele carriage rates, even if the study populations are of the same ethnic background. Nevertheless, some evidence is emerging that polymorphisms in the IL1, IL6,IL10, VDR, and CD14 genes may be associated with CP susceptibility in certain populations. Future studies should apply more strict disease classification, larger study cohorts, adjust for relevant risk factors in CP, and include analysis of multiple genes and polymorphisms. Novel statistical methods may allow a better assessment of multiple genes and polymorphisms within the same pathway and interactions with environmental factors. The possibility to include data from multiple genes and polymorphisms or haplotypes and environmental data, and to model their interactions, will give us a better assessment of $\mathrm{CP}$ and its pathophysiology.

\section{References}

[1] L. N. Borrell and P. N. Papapanou, "Analytical epidemiology of periodontitis," Journal of Clinical Periodontology, vol. 32, supplement 6, pp. 132-158, 2005.

[2] B. S. Michalowicz, S. R. Diehl, J. C. Gunsolley, et al., "Evidence of a substantial genetic basis for risk of adult periodontitis," Journal of Periodontology, vol. 71, no. 11, pp. 1699-1707, 2000.

[3] B. S. Michalowicz, D. Aeppli, J. G. Virag, et al., "Periodontal findings in adult twins," Journal of Periodontology, vol. 62, no. 5, pp. 293-299, 1991.

[4] S. Offenbacher, S. P. Barros, and J. D. Beck, "Rethinking periodontal inflammation," Journal of Periodontology, vol. 79, no. 8, supplement, pp. 1577-1584, 2008.

[5] E. A. Gore, J. J. Sanders, J. P. Pandey, Y. Palesch, and G. M. P. Galbraith, "Interleukin- $1 \beta$ allele 2 : association with disease status in adult periodontitis," Journal of Clinical Periodontology, vol. 25, no. 10, pp. 781-785, 1998.

[6] M. L. Laine, M. A. Farre, M. A. Garcia-González, et al., "Polymorphisms of the interleukin-1 gene family, oral microbial pathogens, and smoking in adult periodontitis," Journal of Dental Research, vol. 80, no. 8, pp. 1695-1699, 2001.

[7] W. M. Thomson, S. J. Edwards, D. P. Dobson-Le, et al., "IL-1 genotype and adult periodontitis among young New Zealanders," Journal of Dental Research, vol. 80, no. 8, pp. 1700-1703, 2001.

[8] M. A. Rogers, L. Figliomeni, K. Baluchova, et al., "Do interleukin-1 polymorphisms predict the development of periodontitis or the success of dental implants?" Journal of Periodontal Research, vol. 37, no. 1, pp. 37-41, 2002.

[9] D. Sakellari, S. Koukoudetsos, M. Arsenakis, and A. Konstantinidis, "Prevalence of IL-1A and IL-1B polymorphisms in a Greek population," Journal of Clinical Periodontology, vol. 30, no. 1, pp. 35-41, 2003.

[10] P. M. Brett, P. Zygogianni, G. S. Griffiths, et al., "Functional gene polymorphisms in aggressive and chronic periodontitis," Journal of Dental Research, vol. 84, no. 12, pp. 1149-1153, 2005.

[11] N. J. Lopez, L. Jara, and C. Y. Valenzuela, "Association of interleukin-1 polymorphisms with periodontal disease," Journal of Periodontology, vol. 76, no. 2, pp. 234-243, 2005.

[12] D. Sakellari, V. Katsares, M. Georgiadou, A. Kouvatsi, M. Arsenakis, and A. Konstantinidis, "No correlation of five gene polymorphisms with periodontal conditions in a Greek population," Journal of Clinical Periodontology, vol. 33, no. 11, pp. 765-770, 2006.

[13] T. Tervonen, T. Raunio, M. Knuuttila, and R. Karttunen, "Polymorphisms in the CD14 and IL-6 genes associated with periodontal disease," Journal of Clinical Periodontology, vol. 34, no. 5, pp. 377-383, 2007.

[14] J. Wagner, W. E. Kaminski, C. Aslanidis, et al., "Prevalence of OPG and IL-1 gene polymorphisms in chronic periodontitis," Journal of Clinical Periodontology, vol. 34, no. 10, pp. 823-827, 2007.

[15] F. Struch, M. Dau, C. Schwahn, R. Biffar, T. Kocher, and P. Meisel, "Interleukin-1 gene polymorphism, diabetes, and periodontitis: results from the Study of Health in Pomerania (SHIP)," Journal of Periodontology, vol. 79, no. 3, pp. 501$507,2008$.

[16] K. Geismar, C. Enevold, L. K. Sorensen, et al., "Involvement of interleukin-1 genotypes in the association of coronary heart disease with periodontitis," Journal of Periodontology, vol. 79, no. 12, pp. 2322-2330, 2008.

[17] S. Shiroddria, J. Smith, I. J. McKay, C. N. Kennett, and F. J. Hughes, "Polymorphisms in the IL-1A gene are correlated with levels of interleukin- $1 \alpha$ protein in gingival crevicular fluid of teeth with severe periodontal disease," Journal of Dental Research, vol. 79, no. 11, pp. 1864-1869, 2000.

[18] O. Anusaksathien, A. Sukboon, P. Sitthiphong, and R. Teanpaisan, "Distribution of interleukin- $1 \beta+3954$ and IL$1 \alpha-889$ genetic variations in a Thai population group," Journal of Periodontology, vol. 74, no. 12, pp. 1796-1802, 2003.

[19] T. Kobayashi, S. Ito, K. Yasuda, et al., "The combined genotypes of stimulatory and inhibitory $\mathrm{Fc} \gamma$ receptors associated with systemic lupus erythematosus and periodontitis in Japanese adults," Journal of Periodontology, vol. 78, no. 3, pp. 467-474, 2007.

[20] T. Kobayashi, S. Ito, T. Kuroda, et al., "The interleukin-1 and $F_{c} \gamma$ receptor gene polymorphisms in Japanese patients with rheumatoid arthritis and periodontitis," Journal of Periodontology, vol. 78, no. 12, pp. 2311-2318, 2007.

[21] L. de S. Gonçalves, S. M. S. Ferreira, C. O. Souza, and A. P. V. Colombo, "IL-1 gene polymorphism and periodontal status of HIV Brazilians on highly active antiretroviral therapy," AIDS, vol. 20, no. 13, pp. 1779-1781, 2006.

[22] P. R. Moreira, J. E. Costa, R. S. Gomez, K. J. Gollob, and W. O. Dutra, "The IL1A (-889) gene polymorphism is associated with chronic periodontal disease in a sample of Brazilian individuals," Journal of Periodontal Research, vol. 42, no. 1, pp. 23-30, 2007.

[23] H. K. Tabor, N. J. Risch, and R. M. Myers, "Candidate-gene approaches for studying complex genetic traits: practical considerations," Nature Reviews Genetics, vol. 3, no. 5, pp. 391-397, 2002.

[24] T. C. Hart, M. L. Marazita, and J. T. Wright, "The impact of molecular genetics on oral health paradigms," Critical Reviews in Oral Biology and Medicine, vol. 11, no. 1, pp. 2656, 2000.

[25] G. M. P. Galbraith, T. M. Hendley, J. J. Sanders, Y. Palesch, and J. P. Pandey, "Polymorphic cytokine genotypes as markers of disease severity in adult periodontitis," Journal of Clinical Periodontology, vol. 26, no. 11, pp. 705-709, 1999.

[26] J. R. Gonzales, J. Michel, E. L. Rodriguez, J. M. Herrmann, R. H. Bodeker, and J. Meyle, "Comparison of interleukin-1 genotypes in two populations with aggressive periodontitis," 
European Journal of Oral Sciences, vol. 111, no. 5, pp. 395399, 2003.

[27] A. Droździk, M. Kurzawski, K. Safronow, and J. Banach, "Polymorphism in interleukin-1beta gene and the risk of periodontitis in a Polish population," Advances in Medical Sciences, vol. 51, supplement 1, pp. 13-17, 2006.

[28] A. Gustafsson, H. Ito, B. Asman, and K. Bergstrom, "Hyperreactive mononuclear cells and neutrophils in chronic periodontitis," Journal of Clinical Periodontology, vol. 33, no. 2, pp. 126-129, 2006.

[29] Y. Soga, F. Nishimura, H. Ohyama, H. Maeda, S. Takashiba, and Y. Murayama, "Tumor necrosis factor-alpha gene (TNFa) $-1031 /-863,-857$ single-nucleotide polymorphisms (SNPs) are associated with severe adult periodontitis in Japanese," Journal of Clinical Periodontology, vol. 30, no. 6, pp. 524-531, 2003.

[30] P. R. Moreira, A. R. de Sa, G. M. Xavier, et al., "A functional interleukin-1 $\beta$ gene polymorphism is associated with chronic periodontitis in a sample of Brazilian individuals," Journal of Periodontal Research, vol. 40, no. 4, pp. 306-311, 2005.

[31] S. B. Ferreira Jr., A. P. F. Trombone, C. E. Repeke, et al., "An interleukin-1 $\beta$ (IL-1 $\beta$ ) single-nucleotide polymorphism at position 3954 and red complex periodontopathogens independently and additively modulate the levels of IL-1 $\beta$ in diseased periodontal tissues," Infection and Immunity, vol. 76, no. 8, pp. 3725-3734, 2008.

[32] G. Kaarthikeyan, N. D. Jayakumar, O. Padmalatha, V. Sheeja, M. Sankari, and B. Anandan, "Analysis of the association between interleukin $-1 \beta(+3954)$ gene polymorphism and chronic periodontitis in a sample of the south Indian population," Indian Journal of Dental Research, vol. 20, no. 1, pp. 37-40, 2009.

[33] U. van der Velden, F. Abbas, S. Armand, et al., "The effect of sibling relationship on the periodontal condition," Journal of Clinical Periodontology, vol. 20, no. 9, pp. 683-690, 1993.

[34] M. D. Petit, T. J. van Steenbergen, M. F. Timmerman, J. de Graaff, and U. van der Velden, "Prevalence of periodontitis and suspected periodontal pathogens in families of adult periodontitis patients," Journal of Clinical Periodontology, vol. 21, no. 2, pp. 76-85, 1994.

[35] A. Berdeli, G. Emingil, A. Gurkan, G. Atilla, and T. Kose, "Association of the IL-1RN2 allele with periodontal diseases," Clinical Biochemistry, vol. 39, no. 4, pp. 357-362, 2006.

[36] K. S. Kornman, A. Crane, H. Y. Wang, et al., "The interleukin1 genotype as a severity factor in adult periodontal disease," Journal of Clinical Periodontology, vol. 24, no. 1, pp. 72-77, 1997.

[37] M. J. McDevitt, H.-Y. Wang, C. Knobelman, et al., "Interleukin-1 genetic association with periodontitis in clinical practice," Journal of Periodontology, vol. 71, no. 2, pp. 156 $163,2000$.

[38] P. N. Papapanou, A.-M. Neiderud, J. Sandros, and G. Dahlen, "Interleukin-1 gene polymorphism and periodontal status: a case-control study," Journal of Clinical Periodontology, vol. 28, no. 5, pp. 389-396, 2001.

[39] P. Meisel, A. Siegemund, R. Grimm, et al., "The interleukin-1 polymorphism, smoking, and the risk of periodontal disease in the population-based SHIP study," Journal of Dental Research, vol. 82, no. 3, pp. 189-193, 2003.

[40] G. C. Armitage, Y. Wu, H.-Y. Wang, J. Sorrell, F. S. Di Giovine, and G. W. Duff, "Low prevalence of a periodontitisassociated interleukin-1 composite genotype in individuals of Chinese heritage," Journal of Periodontology, vol. 71, no. 2, pp. 164-171, 2000.

[41] A. A. Agrawal, A. Kapley, R. K. Yeltiwar, and H. J. Purohit, "Assessment of single nucleotide polymorphism at IL$1 \mathrm{~A}+4845$ and IL-1B+3954 as genetic susceptibility test for chronic periodontitis in Maharashtrian ethnicity," Journal of Periodontology, vol. 77, no. 9, pp. 1515-1521, 2006.

[42] J. Craandijk, M. V. van Krugten, C. L. Verweij, U. van der Velden, and B. G. Loos, "Tumor necrosis factor- $\alpha$ gene polymorphisms in relation to periodontitis," Journal of Clinical Periodontology, vol. 29, no. 1, pp. 28-34, 2002.

[43] G. M. P. Galbraith, R. B. Steed, J. J. Sanders, and J. P. Pandey, "Tumor necrosis factor alpha production by oral leukocytes: influence of tumor necrosis factor genotype," Journal of Periodontology, vol. 69, no. 4, pp. 428-433, 1998.

[44] A. Fassmann, L. I. Holla, D. Buckova, A. Vasku, V. Znojil, and J. Vanek, "Polymorphisms in the $+252(\mathrm{~A} / \mathrm{G})$ lymphotoxinalpha and the $-308(\mathrm{~A} / \mathrm{G})$ tumor necrosis factor-alpha genes and susceptibility to chronic periodontitis in a Czech population," Journal of Periodontal Research, vol. 38, no. 4, pp. 394-399, 2003.

[45] M. Folwaczny, J. Glas, H.-P. Torok, M. Mende, and C. Folwaczny, "Lack of association between the TNF $\alpha \mathrm{G}-308$ A promoter polymorphism and periodontal disease," Journal of Clinical Periodontology, vol. 31, no. 6, pp. 449-453, 2004.

[46] M. Donati, T. Berglundh, A.-M. Hytonen, M. Hahn-Zoric, L.-A. Hanson, and L. Padyukov, "Association of the -159 CD14 gene polymorphism and lack of association of the -308 TNFA and Q551R IL-4RA polymorphisms with severe chronic periodontitis in Swedish Caucasians," Journal of Clinical Periodontology, vol. 32, no. 5, pp. 474-479, 2005.

[47] S. Schulz, H. K. G. Machulla, W. Altermann, et al., "Genetic markers of tumour necrosis factor $\alpha$ in aggressive and chronic periodontitis," Journal of Clinical Periodontology, vol. 35, no. 6, pp. 493-500, 2008.

[48] N. G. de Menezes and A. P. V. Colombo, "Lack of association between the TNF- $\alpha-308$ (G/A) genetic polymorphism and periodontal disease in Brazilians," Brazilian Oral Research, vol. 22, no. 4, pp. 322-327, 2008.

[49] L. I. Holla, A. Fassmann, P. Augustin, T. Halabala, V. Znojil, and J. Vanek, "The association of interleukin-4 haplotypes with chronic periodontitis in a Czech population," Journal of Periodontology, vol. 79, no. 10, pp. 1927-1933, 2008.

[50] R. M. Scarel-Caminaga, P. C. Trevilatto, A. P. Souza, R. B. Brito Jr., and S. R. P. Line, "Investigation of IL4 gene polymorphism in individuals with different levels of chronic periodontitis in a Brazilian population," Journal of Clinical Periodontology, vol. 30, no. 4, pp. 341-345, 2003.

[51] C. C. Pontes, J. R. Gonzales, A. B. Novaes Jr., et al., "Interleukin-4 gene polymorphism and its relation to periodontal disease in a Brazilian population of African heritage," Journal of Dentistry, vol. 32, no. 3, pp. 241-246, 2004.

[52] B. Hooshmand, M. Hajilooi, A. Rafiei, K. H. Mani-Kashani, and R. Ghasemi, "Interleukin-4 (C-590T) and interferon- $\gamma$ (G5644A) gene polymorphisms in patients with periodontitis," Journal of Periodontal Research, vol. 43, no. 1, pp. 111115, 2008.

[53] P. Stashenko, P. Fujiyoshi, M. S. Obernesser, L. Prostak, A. D. Haffajee, and S. S. Socransky, "Levels of interleukin 1 beta in tissue from sites of active periodontal disease," Journal of Clinical Periodontology, vol. 18, no. 7, pp. 548-554, 1991.

[54] Y. Ishihara, T. Nishihara, T. Kuroyanagi, et al., "Gingival crevicular interleukin-1 and interleukin-1 receptor antagonist levels in periodontally healthy and diseased sites," Journal of Periodontal Research, vol. 32, no. 6, pp. 524-529, 1997. 
[55] F. Pociot, J. Molvig, L. Wogensen, H. Worsaae, and J. Nerup, "A TaqI polymorphism in the human interleukin-1 $\beta$ (IL$1 \beta$ ) gene correlates with IL- $1 \beta$ secretion in vitro," European Journal of Clinical Investigation, vol. 22, no. 6, pp. 396-402, 1992.

[56] T. Andus, R. Daig, D. Vogl, et al., "Imbalance of the interleukin 1 system in colonic mucosa-association with intestinal inflammation and interleukin 1 receptor agonist genotype 2," Gut, vol. 41, no. 5, pp. 651-657, 1997.

[57] L. I. Holla, A. Fassmann, A. Stejskalova, V. Znojil, J. Vanek, and J. Vacha, "Analysis of the interleukin-6 gene promoter polymorphisms in Czech patients with chronic periodontitis," Journal of Periodontology, vol. 75, no. 1, pp. 30-36, 2004.

[58] N. Babel, G. Cherepnev, D. Babel, et al., "Analysis of tumor necrosis factor- $\beta$, transforming growth factor- $\beta$, interleukin10 , IL-6, and interferon- $\gamma$ gene polymorphisms in patients with chronic periodontitis," Journal of Periodontology, vol. 77, no. 12, pp. 1978-1983, 2006.

[59] J. C. Wohlfahrt, T. Wu, J. S. Hodges, J. E. Hinrichs, and B. S. Michalowicz, "No association between selected candidate gene polymorphisms and severe chronic periodontitis," Journal of Periodontology, vol. 77, no. 3, pp. 426-436, 2006.

[60] L. Nibali, F. D’Aiuto, N. Donos, et al., "Association between periodontitis and common variants in the promoter of the interleukin-6 gene," Cytokine, vol. 45, no. 1, pp. 50-54, 2009.

[61] P. C. Trevilatto, R. M. Scarel-Caminaga, R. B. de Brito Jr., A. P. de Souza, and S. R. P. Line, "Polymorphism at position -174 of IL-6 gene is associated with susceptibility to chronic periodontitis in a Caucasian Brazilian population," Journal of Clinical Periodontology, vol. 30, no. 5, pp. 438-442, 2003.

[62] Y. Komatsu, H. Tai, J. C. Galicia, et al., "Interleukin-6 (IL6) - 373 A9T11 allele is associated with reduced susceptibility to chronic periodontitis in Japanese subjects and decreased serum IL-6 level," Tissue Antigens, vol. 65, no. 1, pp. 110-114, 2005.

[63] P. R. Moreira, P. M. A. Lima, K. O. B. Sathler, et al., "Interleukin-6 expression and gene polymorphism are associated with severity of periodontal disease in a sample of Brazilian individuals," Clinical and Experimental Immunology, vol. 148, no. 1, pp. 119-126, 2007.

[64] J. C. Galicia, H. Tai, Y. Komatsu, Y. Shimada, I. Ikezawa, and H. Yoshie, "Interleukin-6 receptor gene polymorphisms and periodontitis in a non-smoking Japanese population," Journal of Clinical Periodontology, vol. 33, no. 10, pp. 704709, 2006 .

[65] T. Berglundh, M. Donati, M. Hahn-Zoric, L.-A. Hanson, and L. Padyukov, "Association of the -1087 IL 10 gene polymorphism with severe chronic periodontitis in Swedish Caucasians," Journal of Clinical Periodontology, vol. 30, no. 3, pp. 249-254, 2003.

[66] S. Reichert, H. K. G. MacHulla, J. Klapproth, et al., "The interleukin-10 promoter haplotype ATA is a putative risk factor for aggressive periodontitis," Journal of Periodontal Research, vol. 43, no. 1, pp. 40-47, 2008.

[67] R. M. Scarel-Caminaga, P. C. Trevilatto, A. P. Souza, R. B. Brito, L. E. A. Camargo, and S. R. P. Line, "Interleukin 10 gene promoter polymorphisms are associated with chronic periodontitis," Journal of Clinical Periodontology, vol. 31, no. 6, pp. 443-448, 2004.

[68] A. P. Sumer, N. Kara, G. C. Keles, S. Gunes, H. Koprulu, and H. Bagci, "Association of interleukin-10 gene polymorphisms with severe generalized chronic periodontitis," Journal of Periodontology, vol. 78, no. 3, pp. 493-497, 2007.

[69] M. Claudino, A. P. F. Trombone, C. R. Cardoso, et al., "The broad effects of the functional IL-10 promoter-592 polymorphism: modulation of IL-10, TIMP-3, and OPG expression and their association with periodontal disease outcome," Journal of Leukocyte Biology, vol. 84, no. 6, pp. 1565-1573, 2008.

[70] A. P. Colombo, C. Eftimiadi, A. D. Haffajee, M. A. Cugini, and S. S. Socransky, "Serum IgG2 level, Gm(23) allotype and $\mathrm{Fc} \gamma$ RIIa and $\mathrm{Fc} \gamma \mathrm{RIIIb}$ receptors in refractory periodontal disease," Journal of Clinical Periodontology, vol. 25, no. 6, pp. 465-474, 1998.

[71] B. G. Loos, F. G. J. Leppers-Van de Straat, J. G. J. Van de Winkel, and U. Van der Velden, "Fcy receptor polymorphisms in relation to periodontitis," Journal of Clinical Periodontology, vol. 30, no. 7, pp. 595-602, 2003.

[72] K. Yamamoto, T. Kobayashi, S. Grossi, et al., "Association of Fc $\gamma$ receptor IIa genotype with chronic periodontitis in Caucasians," Journal of Periodontology, vol. 75, no. 4, pp. 517522, 2004.

[73] D. L. Wolf, A. M. Neiderud, K. Hinckley, G. Dahlén, J. G. J. Van de Winkel, and P. N. Papapanou, "Fcy receptor polymorphisms and periodontal status: a prospective followup study," Journal of Clinical Periodontology, vol. 33, no. 10, pp. 691-698, 2006.

[74] T. Kobayashi, N. A. C. Westerdaal, A. Miyazaki, et al., "Relevance of immunoglobulin G Fc receptor polymorphism to recurrence of adult periodontitis in Japanese patients," Infection and Immunity, vol. 65, no. 9, pp. 3556-3560, 1997.

[75] T. Kobayashi, N. Sugita, W.-L. van der Pol, et al., "The Fcy receptor genotype as a risk factor for generalized early-onset periodontitis in Japanese patients," Journal of Periodontology, vol. 71, no. 9, pp. 1425-1432, 2000.

[76] T. Kobayashi, K. Yamamoto, N. Sugita, et al., "The Fcy receptor genotype as a severity factor for chronic periodontitis in Japanese patients," Journal of Periodontology, vol. 72, no. 10, pp. 1324-1331, 2001.

[77] H.-Y. Chung, H.-C. Lu, W.-L. Chen, C.-T. Lu, Y.-H. Yang, and C.-C. Tsai, "Gm (23) allotypes and Fcy receptor genotypes as risk factors for various forms of periodontitis," Journal of Clinical Periodontology, vol. 30, no. 11, pp. 954-960, 2003.

[78] N. Sugita, K. Yamamoto, T. Kobayashi, et al., "Relevance of Fc $\gamma$ RIIIa-158V-F polymorphism to recurrence of adult periodontitis in Japanese patients," Clinical and Experimental Immunology, vol. 117, no. 2, pp. 350-354, 1999.

[79] N. Sugita, T. Kobayashi, Y. Ando, et al., "Increased frequency of Fc $\gamma$ RIIIb-NA1 allele in periodontitis-resistant subjects in an elderly Japanese population," Journal of Dental Research, vol. 80, no. 3, pp. 914-918, 2001.

[80] A. Yoshihara, N. Sugita, K. Yamamoto, T. Kobayashi, H. Miyazaki, and H. Yoshie, "Analysis of vitamin D and Fcy receptor polymorphisms in Japanese patients with generalized early-onset periodontitis," Journal of Dental Research, vol. 80, no. 12, pp. 2051-2054, 2001.

[81] L. Nibali, M. Parkar, F. D'Aiuto, et al., "Vitamin D receptor polymorphism ( -1056 Taq-I) interacts with smoking for the presence and progression of periodontitis," Journal of Clinical Periodontology, vol. 35, no. 7, pp. 561-567, 2008.

[82] J. L. Sun, H. X. Meng, C. F. Cao, et al., "Relationship between vitamin D receptor gene polymorphism and periodontitis," Journal of Periodontal Research, vol. 37, no. 4, pp. 263-267, 2002. 
[83] Y. Tachi, H. Shimpuku, Y. Nosaka, et al., "Vitamin D receptor gene polymorphism is associated with chronic periodontitis," Life Sciences, vol. 73, no. 26, pp. 3313-3321, 2003.

[84] R. B. de Brito Jr., R. M. Scarel-Caminaga, P. C. Trevilatto, A. P. de Souza, and S. P. Barros, "Polymorphisms in the vitamin D receptor gene are associated with periodontal disease," Journal of Periodontology, vol. 75, no. 8, pp. 1090-1095, 2004.

[85] S. Gunes, A. P. Sumer, G. C. Keles, et al., "Analysis of vitamin $\mathrm{D}$ receptor gene polymorphisms in patients with chronic periodontitis," Indian Journal of Medical Research, vol. 127, no. 1, pp. 58-64, 2008.

[86] M. Naito, K. Miyaki, T. Naito, et al., "Association between vitamin $\mathrm{D}$ receptor gene haplotypes and chronic periodontitis among Japanese men," International Journal of Medical Sciences, vol. 4, no. 4, pp. 216-222, 2007.

[87] L. I. Holla, D. Buckova, A. Fassman, T. Halabala, A. Vasku, and J. Vacha, "Promoter polymorphisms in the CD14 receptor gene and their potential association with the severity of chronic periodontitis," Journal of Medical Genetics, vol. 39, no. 11, pp. 844-848, 2002.

[88] M. Folwaczny, J. Glas, H.-P. Torok, K. Fricke, and C. Folwaczny, "The CD14 -159C-to-T promoter polymorphism in periodontal disease," Journal of Clinical Periodontology, vol. 31, no. 11, pp. 991-995, 2004.

[89] M. L. Laine, S. A. Morré, L. S. Murillo, A.-J. van Winkelhoff, and A. S. Peña, "CD14 and TLR4 gene polymorphisms in adult periodontitis," Journal of Dental Research, vol. 84, no. 11, pp. 1042-1046, 2005.

[90] J. A. James, K. V. Poulton, S. E. Haworth, et al., "Polymorphisms of TLR4 but not CD14 are associated with a decreased risk of aggressive periodontitis," Journal of Clinical Periodontology, vol. 34, no. 2, pp. 111-117, 2007.

[91] S. Schulz, N. Zissler, W. Altermann, et al., "Impact of genetic variants of CD14 and TLR4 on subgingival periodontopathogens," International Journal of Immunogenetics, vol. 35, no. 6, pp. 457-464, 2008.

[92] E. A. Nicu, M. L. Laine, S. A. Morré, U. Van der Velden, and B. G. Loos, "Soluble CD14 in periodontitis," Innate Immunity, vol. 15, no. 2, pp. 121-128, 2009.

[93] K. Yamazaki, K. Ueki-Maruyama, T. Oda, et al., "Singlenucleotide polymorphism in the CD14 promoter and periodontal disease expression in a Japanese population," Journal of Dental Research, vol. 82, no. 8, pp. 612-616, 2003.

[94] A. Berdeli, G. Emingil, B. Han Saygan, et al., "TLR2 Arg753Gly, TLR4 Asp299Gly and Thr399Ile gene polymorphisms are not associated with chronic periodontitis in a Turkish population," Journal of Clinical Periodontology, vol. 34, no. 7, pp. 551-557, 2007.

[95] T. Fukusaki, N. Ohara, Y. Hara, A. Yoshimura, and K. Yoshiura, "Evidence for association between a Toll-like receptor 4 gene polymorphism and moderate/severe periodontitis in the Japanese population," Journal of Periodontal Research, vol. 42, no. 6, pp. 541-545, 2007.

[96] G. Zhu, C. Li, Z. Cao, E. F. Corbet, and L. Jin, “Tolllike receptors 2 and 4 gene polymorphisms in a Chinese population with periodontitis," Quintessence International, vol. 39, no. 3, pp. 217-226, 2008.

[97] L. I. Holla, D. Buckova, A. Fassmann, L. Roubalikova, and J. Vanek, "Lack of association between chronic periodontitis and the Toll-like receptor 4 gene polymorphisms in a Czech population," Journal of Periodontal Research, vol. 42, no. 4, pp. 340-344, 2007.

[98] L. I. Holla, A. Fassman, A. Vasku, V. Znojil, J. Vanek, and J. Vacha, "Interactions of lymphotoxin $\alpha$ (TNF- $\beta)$, anqiotensin-converting enzyme (ACE), and endothelin-1 (ET-1) gene polymorphisms in adult periodontitis," Journal of Periodontology, vol. 72, no. 1, pp. 85-89, 2001.

[99] J. Glas, H.-P. Torok, L. Tonenchi, et al., "A645G (Lys216Glu) polymorphism of the bactericidal/permeability-increasing protein gene in periodontal disease," International Journal of Immunogenetics, vol. 33, no. 4, pp. 255-260, 2006.

[100] M. Folwaczny, J. Glas, H.-P. Torok, D. Mauermann, and C. Folwaczny, "The 3020insC mutation of the NOD2/CARD15 gene in patients with periodontal disease," European Journal of Oral Sciences, vol. 112, no. 4, pp. 316-319, 2004.

[101] M. L. Laine, L. S. Murillo, S. A. Morré, E. G. Winkel, A. S. Peña, and A. J. van Winkelhoff, "CARD15 gene mutations in periodontitis," Journal of Clinical Periodontology, vol. 31, no. 10, pp. 890-893, 2004.

[102] M. Folwaczny, J. Glas, H.-P. Torok, K. Fricke, and C. Folwaczny, "Prevalence of the chemokine receptor CCR5- $\Delta 32$ gene mutation in periodontal disease," Clinical Immunology, vol. 109, no. 3, pp. 325-329, 2003.

[103] L. Savarrio, M. Donati, C. Carr, D. F. Kinane, and T. Berglundh, "Interleukin-24, RANTES and CCR5 gene polymorphisms are not associated with chronic adult periodontitis," Journal of Periodontal Research, vol. 42, no. 2, pp. 152158, 2007.

[104] Y.-P. Ho, Y.-C. Lin, Y.-H. Yang, K.-Y. Ho, Y.-M. Wu, and C.-C. Tsai, "Cyclooxygenase-2 Gene-765 single nucleotide polymorphism as a protective factor against periodontitis in Taiwanese," Journal of Clinical Periodontology, vol. 35, no. 1, pp. 1-8, 2008.

[105] C.-J. Xie, L.-M. Xiao, W.-H. Fan, D.-Y. Xuan, and J.C. Zhang, "Common single nucleotide polymorphisms in cyclooxygenase- 2 and risk of severe chronic periodontitis in a Chinese population," Journal of Clinical Periodontology, vol. 36, no. 3, pp. 198-203, 2009.

[106] A. Berdeli, A. Gurkan, G. Emingil, G. Atilla, and T. Kose, "Endothelial nitric oxide synthase Glu298Asp gene polymorphism in periodontal diseases," Journal of Periodontology, vol. 77, no. 8, pp. 1348-1354, 2006.

[107] L. Zhang, H. Meng, H. Zhao, et al., "Estrogen receptor- $\alpha$ gene polymorphisms in patients with periodontitis," Journal of Periodontal Research, vol. 39, no. 5, pp. 362-366, 2004.

[108] B. Houshmand, A. Rafiei, M. Hajilooi, K. Mani-Kashani, and L. Gholami, "E-selectin and L-selectin polymorphisms in patients with periodontitis," Journal of Periodontal Research, vol. 44, no. 1, pp. 88-93, 2009.

[109] S. E. Sahingur, A. Sharma, R. J. Genco, and E. De Nardin, "Association of increased levels of fibrinogen ad the $-455 \mathrm{G} / \mathrm{A}$ fibrinogen gene polymorphism with chronic periodontitis," Journal of Periodontology, vol. 74, no. 3, pp. 329-337, 2003.

[110] K. Yasuda, N. Sugita, T. Kobayashi, K. Yamamoto, and H. Yoshie, "Fc $\gamma$ RIIB gene polymorphisms in Japanese periodontitis patients," Genes and Immunity, vol. 4, no. 8, pp. 541-546, 2003.

[111] P. Concolino, F. Cecchetti, C. D’Autilia, et al., "Association of periodontitis with GSTM1/GSTT1-null variants-a pilot study," Clinical Biochemistry, vol. 40, no. 13-14, pp. 939-945, 2007.

[112] S. Reichert, H. K. G. Machulla, J. Klapproth, et al., "Interferon-gamma and interleukin-12 gene polymorphisms and their relation to aggressive and chronic periodontitis and key periodontal pathogens," Journal of Periodontology, vol. 79, no. 8, pp. 1434-1443, 2008.

[113] D. A. Fraser, B. G. Loos, U. Boman, et al., "Polymorphisms in an interferon- $\gamma$ receptor- 1 gene marker and susceptibility to 
periodontitis," Acta Odontologica Scandinavica, vol. 61, no. 5, pp. 297-302, 2003.

[114] R. M. Scarel-Caminaga, P. C. Trevilatto, A. P. Souza, R. B. Brito Jr., and S. R. P. Line, "Investigation of an IL-2 polymorphism in patients with different levels of chronic periodontitis," Journal of Clinical Periodontology, vol. 29, no. 7, pp. 587-591, 2002.

[115] K. Takeuchi-Hatanaka, H. Ohyama, F. Nishimura, et al., "Polymorphisms in the 5' flanking region of IL12RB2 are associated with susceptibility to periodontal diseases in the Japanese population," Journal of Clinical Periodontology, vol. 35, no. 4, pp. 317-323, 2008.

[116] M. Folwaczny, J. Glas, H.-P. Torok, et al., "Prevalence of the -295 T-to-C promoter polymorphism of the interleukin (IL)-16 gene in periodontitis," Clinical and Experimental Immunology, vol. 142, no. 1, pp. 188-192, 2005.

[117] M. Folwaczny, J. Glas, H.-P. Torok, et al., "Polymorphisms of the interleukin-18 gene in periodontitis patients," Journal of Clinical Periodontology, vol. 32, no. 5, pp. 530-534, 2005.

[118] Y.-M. Wu, S.-H. Juo, Y.-P. Ho, K.-Y. Ho, Y.-H. Yang, and C.-C. Tsai, "Association between lactoferrin gene polymorphisms and aggressive periodontitis among Taiwanese patients," Journal of Periodontal Research, vol. 44, no. 3, pp. 418-424, 2009.

[119] A. Louropoulou, U. van der Velden, T. Schoenmaker, A. Catsburg, P. H. M. Savelkoul, and B. G. Loos, "Mannosebinding lectin gene polymorphisms in relation to periodontitis," Journal of Clinical Periodontology, vol. 35, no. 11, pp. 923-930, 2008.

[120] A. Tsutsumi, T. Kobayashi, S. Ito, et al., "Mannose binding lectin gene polymorphism and the severity of chronic periodontitis," Nihon Rinsho Meneki Gakkai Kaishi, vol. 32, pp. 48-52, 2009.

[121] A. P. de Souza, P. C. Trevilatto, R. M. Scarel-Caminaga, R. B. Brito Jr., and S. R. P. Line, "MMP-1 promoter polymorphism: association with chronic periodontitis severity in a Brazilian population," Journal of Clinical Periodontology, vol. 30, no. 2, pp. 154-158, 2003.

[122] L. I. Holla, M. Jurajda, A. Fassmann, N. Dvorakova, V. Znojil, and J. Vacha, "Genetic variations in the matrix metalloproteinase-1 promoter and risk of susceptibility and/or severity of chronic periodontitis in the Czech population," Journal of Clinical Periodontology, vol. 31, no. 8, pp. 685-690, 2004.

[123] M. Itagaki, T. Kubota, H. Tai, Y. Shimada, T. Morozumi, and K. Yamazaki, "Matrix metalloproteinase-1 and-3 gene promoter polymorphisms in Japanese patients with periodontitis," Journal of Clinical Periodontology, vol. 31, no. 9, pp. 764-769, 2004.

[124] C. M. Astolfi, A. L. Shinohara, R. A. da Silva, M. C. L. G. Santos, S. R. P. Line, and A. P. de Souza, "Genetic polymorphisms in the MMP-1 and MMP-3 gene may contribute to chronic periodontitis in a Brazilian population," Journal of Clinical Periodontology, vol. 33, no. 10, pp. 699-703, 2006.

[125] Z. Cao, C. Li, L. Jin, and E. F. Corbet, "Association of matrix metalloproteinase-1 promoter polymorphism with generalized aggressive periodontitis in a Chinese population," Journal of Periodontal Research, vol. 40, no. 6, pp. 427431, 2005.

[126] D. Pirhan, G. Atilla, G. Emingil, T. Sorsa, T. Tervahartiala, and A. Berdeli, "Effect of MMP-1 promoter polymorphisms on GCF MMP-1 levels and outcome of periodontal therapy in patients with severe chronic periodontitis," Journal of Clinical Periodontology, vol. 35, no. 10, pp. 862-870, 2008.
[127] K. Ustun, N. O. Alptekin, S. S. Hakki, and E. E. Hakki, "Investigation of matrix metalloproteinase-1 -1607 1G/2G polymorphism in a Turkish population with periodontitis," Journal of Clinical Periodontology, vol. 35, no. 12, pp. 10131019, 2008.

[128] L. I. Holla, A. Fassmann, A. Vasku, et al., "Genetic variations in the human gelatinase A (matrix metalloproteinase-2) promoter are not associated with susceptibility to, and severity of, chronic periodontitis," Journal of Periodontology, vol. 76, no. 7, pp. 1056-1060, 2005.

[129] A. Gurkan, G. Emingil, B. H. Saygan, et al., "Gene polymorphisms of matrix metalloproteinase-2, -9 and -12 in periodontal health and severe chronic periodontitis," Archives of Oral Biology, vol. 53, no. 4, pp. 337-345, 2008.

[130] A. P. de Souza, P. C. Trevilatto, R. M. Scarel-Caminaga, R. B. de Brito Jr., S. P. Barros, and S. R. P. Line, "Analysis of the MMP-9 (C-1562 T) and TIMP-2 (G-418C) gene promoter polymorphisms in patients with chronic periodontitis," Journal of Clinical Periodontology, vol. 32, no. 2, pp. 207-211, 2005.

[131] L. I. Holla, A. Fassmann, J. Muzik, J. Vanek, and A. Vasku, "Functional polymorphisms in the matrix metalloproteinase-9 gene in relation to severity of chronic periodontitis," Journal of Periodontology, vol. 77, no. 11, pp. 1850-1855, 2006.

[132] G. C. Keles, S. Gunes, A. P. Sumer, et al., "Association of matrix metalloproteinase-9 promoter gene polymorphism with chronic periodontitis," Journal of Periodontology, vol. 77, no. 9, pp. 1510-1514, 2006.

[133] P. Meisel, T. Krause, I. Cascorbi, et al., "Gender and smokingrelated risk reduction of periodontal disease with variant myeloperoxidase alleles," Genes and Immunity, vol. 3, no. 2, pp. 102-106, 2002.

[134] P. Meisel, R. Timm, H. Sawaf, J. Fanghanel, W. Siegmund, and T. Kocher, "Polymorphism of the N-acetyltransferase (NAT2), smoking and the potential risk of periodontal disease," Archives of Toxicology, vol. 74, no. 6, pp. 343-348, 2000.

[135] T. Kocher, H. Sawaf, J. Fanghanel, R. Timm, and P. Meisel, "Association between bone loss in periodontal disease and polymorphism of N-acetyltransferase (NAT2)," Journal of Clinical Periodontology, vol. 29, no. 1, pp. 21-27, 2002.

[136] C. S. Baioni, C. M. de Souza, A. P. Ribeiro Braosi, et al., "Analysis of the association of polymorphism in the osteoprotegerin gene with susceptibility to chronic kidney disease and periodontitis," Journal of Periodontal Research, vol. 43, no. 5, pp. 578-584, 2008.

[137] O.-J. Park, S.-Y. Shin, Y. Choi, et al., "The association of osteoprotegerin gene polymorphisms with periodontitis," Oral Diseases, vol. 14, no. 5, pp. 440-444, 2008.

[138] L. I. Holla, D. Bučková, A. Fassmann, P. Beneš, and V. Znojil, "Plasminogen-activator-inhibitor-1 promoter polymorphism as a risk factor for adult periodontitis in nonsmokers," Genes and Immunity, vol. 3, no. 5, pp. 292-294, 2002.

[139] A. Gurkan, G. Emingil, B. H. Saygan, et al., "Tissue plasminogen activator and plasminogen activator inhibitor-1 gene polymorphisms in patients with chronic periodontitis," Journal of Periodontology, vol. 78, no. 7, pp. 1256-1263, 2007.

[140] L. I. Holla, K. Kankova, A. Fassmann, et al., "Distribution of the receptor for advanced glycation end products gene polymorphisms in patients with chronic periodontitis: a preliminary study," Journal of Periodontology, vol. 72, no. 12, pp. 1742-1746, 2001. 
[141] Q. Y. Li, H. X. Meng, L. Zhang, et al., "Correlation between single nucleotide polymorphisms in a calprotectin subunit gene and risk of periodontitis in a Chinese population," Annals of Human Genetics, vol. 71, no. 3, pp. 312-324, 2007.

[142] J. Glas, V. Beynon, B. Bachstein, et al., "Increased plasma concentration of surfactant protein D in chronic periodontitis independent of SFTPD genotype: potential role as a biomarker," Tissue Antigens, vol. 72, no. 1, pp. 21-28, 2008.

[143] L. I. Holla, A. Fassmann, P. Benes, T. Halabala, and V. Znojil, " 5 polymorphisms in the transforming growth factor- $\beta 1$ gene (TGF- $\beta$ 1) in adult periodontitis," Journal of Clinical Periodontology, vol. 29, no. 4, pp. 336-341, 2002.

[144] A. P. de Souza, P. C. Trevilatto, R. M. Scarel-Caminaga, R. B. de Brito Jr., and S. R. P. Line, "Analysis of the TGF- $\beta 1$ promoter polymorphism (C-509T) in patients with chronic periodontitis," Journal of Clinical Periodontology, vol. 30, no. 6, pp. 519-523, 2003.

[145] G. Atilla, G. Emingil, T. Kose, and A. Berdeli, "TGF$\beta 1$ gene polymorphisms in periodontal diseases," Clinical Biochemistry, vol. 39, no. 9, pp. 929-934, 2006.

[146] Y. Shimada, H. Tai, M. Endo, T. Kobayashi, K. Akazawa, and K. Yamazaki, "Association of tumor necrosis factor receptor type $2+587$ gene polymorphism with severe chronic periodontitis," Journal of Clinical Periodontology, vol. 31, no. 6, pp. 463-469, 2004.

[147] S. S. Socransky, A. D. Haffajee, C. Smith, and G. W. Duff, "Microbiological parameters associated with IL-1 gene polymorphisms in periodontitis patients," Journal of Clinical Periodontology, vol. 27, no. 11, pp. 810-818, 2000.

[148] G. K. Nikolopoulos, N. L. Dimou, S. J. Hamodrakas, and P. G. Bagos, "Cytokine gene polymorphisms in periodontal disease: a meta-analysis of 53 studies including 4178 cases and 4590 controls," Journal of Clinical Periodontology, vol. 35, no. 9, pp. 754-767, 2008.

[149] P. H. Hart, G. F. Vitti, D. R. Burgess, G. A. Whitty, D. S. Piccoli, and J. A. Hamilton, "Potential antiinflammatory effects of interleukin 4: suppression of human monocyte tumor necrosis factor $\alpha$, interleukin 1, and prostagandin $\mathrm{E}_{2}$," Proceedings of the National Academy of Sciences of the United States of America, vol. 86, no. 10, pp. 3803-3807, 1989.

[150] T. Kishimoto, "Interleukin-6 and its receptor in autoimmunity," Journal of Autoimmunity, vol. 5, supplement 1, pp. 123 132, 1992.

[151] P. C. Taylor and M. Feldmann, "New approaches to therapeutic immunomodulation for immune-mediated inflammatory disorders," Current Opinion in Pharmacology, vol. 4, no. 4, pp. 368-371, 2004.

[152] D. Fishman, G. Faulds, R. Jeffey, et al., "The effect of novel polymorphisms in the interleukin-6 (IL-6) gene on IL-6 transcription and plasma IL-6 levels, and an association with systemic-onset juvenile chronic arthritis," Journal of Clinical Investigation, vol. 102, no. 7, pp. 1369-1376, 1998.

[153] F. Rousset, E. Garcia, T. Defrance, et al., "Interleukin 10 is a potent growth and differentiation factor for activated human B lymphocytes," Proceedings of the National Academy of Sciences of the United States of America, vol. 89, no. 5, pp. 1890-1893, 1992.

[154] B. Afar, D. Engel, and E. A. Clark, "Activated lymphocyte subsets in adult periodontitis," Journal of Periodontal Research, vol. 27, no. 2, pp. 126-133, 1992.

[155] T. Berglundh, B. Liljenberg, A. Tarkowski, and J. Lindhe, "The presence of local and circulating autoreactive B cells in patients with advanced periodontitis," Journal of Clinical Periodontology, vol. 29, no. 4, pp. 281-286, 2002.

[156] T. Koutouzis, D. Haber, L. Shaddox, I. Aukhil, and S. M. Wallet, "autoreactivity of serum immunoglobulin to periodontal tissue components: a pilot study," Journal of Periodontology, vol. 80, no. 4, pp. 625-633, 2009.

[157] E. Crawley, R. Kay, J. Sillibourne, P. Patel, I. Hutchinson, and P. Woo, "Polymorphic haplotypes of the interleukin$105^{\prime}$-flanking region determine variable interleukin-10 transcription and are associated with particular phenotypes of juvenile rheumatoid arthritis," Arthritis and Rheumatism, vol. 42, no. 6, pp. 1101-1108, 1999.

[158] K. Koss, J. Satsangi, G. C. Fanning, K. I. Welsh, and D. P. Jewell, "Cytokine (TNF $\alpha$, LT $\alpha$ and IL-10) polymorphisms in inflammatory bowel diseases and normal controls: differential effects on production and allele frequencies," Genes and Immunity, vol. 1, no. 3, pp. 185-190, 2000.

[159] G. P. Garlet, W. Martins Jr., B. A. L. Fonseca, B. R. Ferreira, and J. S. Silva, "Matrix metalloproteinases, their physiological inhibitors and osteoclast factors are differentially regulated by the cytokine profile in human periodontal disease," Journal of Clinical Periodontology, vol. 31, no. 8, pp. 671-679, 2004.

[160] X. Zhang and Y.-T. A. Teng, "Interleukin-10 inhibits gramnegative-microbe-specific human receptor activator of NF$\kappa \mathrm{B}$ ligand-positive $\mathrm{CD} 4^{+}$-Th1-cell-associated alveolar bone loss in vivo," Infection and Immunity, vol. 74, no. 8, pp. 49274931, 2006.

[161] K. Yamazaki, K. Tabeta, T. Nakajima, et al., "Interleukin10 gene promoter polymorphism in Japanese patients with adult and early-onset periodontitis," Journal of Clinical Periodontology, vol. 28, no. 9, pp. 828-832, 2001.

[162] Z.-N. Yuan, O. Schreurs, P. Gjermo, K. Helgeland, and K. Schenck, "Topical distribution of Fc $\gamma$ RI, Fc $\gamma$ RII and Fc $\gamma$ RIII in inflamed human gingiva," Journal of Clinical Periodontology, vol. 26, no. 7, pp. 441-447, 1999.

[163] E. A. Nicu, U. Van der Velden, V. Everts, A. J. Van Winkelhoff, D. Roos, and B. G. Loos, "Hyper-reactive PMNs in Fc $y$ RIIa $131 \mathrm{H} / \mathrm{H}$ genotype periodontitis patients," Journal of Clinical Periodontology, vol. 34, no. 11, pp. 938-945, 2007.

[164] W.-L. van der Pol and J. G. J. van de Winkel, "IgG receptor polymorphisms: risk factors for disease," Immunogenetics, vol. 48, no. 3, pp. 222-232, 1998.

[165] N. M. van Sorge, W.-L. van der Pol, and J. G. J. van de Winkel, "Fc $\gamma \mathrm{R}$ polymorphisms: implications for function, disease susceptibility and immunotherapy," Tissue Antigens, vol. 61, no. 3, pp. 189-202, 2003.

[166] B. G. Loos, R. P. John, and M. L. Laine, "Identification of genetic risk factors for periodontitis and possible mechanisms of action," Journal of Clinical Periodontology, vol. 32, supplement 6, pp. 159-179, 2005.

[167] P. Selvaraj, G. Chandra, M. S. Jawahar, M. V. Rani, D. N. Rajeshwari, and P. R. Narayanan, "Regulatory role of vitamin $\mathrm{D}$ receptor gene variants of BsmI, ApaI, TaqI, and FokI polymorphisms on macrophage phagocytosis and lymphoproliferative response to mycobacterium tuberculosis antigen in pulmonary tuberculosis," Journal of Clinical Immunology, vol. 24 , no. 5, pp. 523-532, 2004.

[168] C. M. Gelder, K. W. Hart, O. M. Williams, et al., "Vitamin D receptor gene polymorphisms and susceptibility to Mycobacterium malmoense pulmonary disease," Journal of Infectious Diseases, vol. 181, no. 6, pp. 2099-2102, 2000.

[169] D. E. Roth, G. Soto, F. Arenas, et al., "Association between vitamin $\mathrm{D}$ receptor gene polymorphisms and response to 
treatment of pulmonary tuberculosis," Journal of Infectious Diseases, vol. 190, no. 5, pp. 920-927, 2004.

[170] C. Gross, T. R. Eccleshall, P. J. Malloy, M. L. Villa, R. Marcus, and D. Feldman, "The presence of a polymorphism at the translation initiation site of the vitamin D receptor gene is associated with low bone mineral density in postmenopausal Mexican-American women," Journal of Bone and Mineral Research, vol. 11, no. 12, pp. 1850-1855, 1996.

[171] J. A. Hubacek, G. Rothe, J. Pit'ha, et al., "C $(-260) \rightarrow \mathrm{T}$ polymorphism in the promoter of the CD14 monocyte receptor gene as a risk factor for myocardial infarction," Circulation, vol. 99, no. 25, pp. 3218-3220, 1999.

[172] W. Klein, A. Tromm, T. Griga, et al., "A polymorphism in the CD14 gene is associated with crohn disease," Scandinavian Journal of Gastroenterology, vol. 37, no. 2, pp. 189-191, 2002.

[173] T. D. LeVan, J. W. Bloom, T. J. Bailey, et al., "A common single nucleotide polymorphism in the CD14 promoter decreases the affinity of Sp protein binding and enhances transcriptional activity," Journal of Immunology, vol. 167, no. 10, pp. 5838-5844, 2001.

[174] P.-Y. Bochud, T. R. Hawn, and A. Aderem, "Cutting edge: a Toll-like receptor 2 polymorphism that is associated with lepromatous leprosy is unable to mediate mycobacterial signaling," Journal of Immunology, vol. 170, no. 7, pp. 34513454, 2003.

[175] N. C. Arbour, E. Lorenz, B. C. Schutte, et al., "TLR4 mutations are associated with endotoxin hyporesponsiveness in humans," Nature Genetics, vol. 25, no. 2, pp. 187-191, 2000.

[176] D. M. Agnese, J. E. Calvano, S. J. Hahm, et al., "Human Toll-like receptor 4 mutations but not CD14 polymorphisms are associated with an increased risk of gram-negative infections," Journal of Infectious Diseases, vol. 186, no. 10, pp. 1522-1525, 2002.

[177] M. Folwaczny, J. Glas, H.-P. Torok, O. Limbersky, and C. Folwaczny, "Toll-like receptor (TLR) 2 and 4 mutations in periodontal disease," Clinical and Experimental Immunology, vol. 135, no. 2, pp. 330-335, 2004.

[178] J. P. A. Ioannidis, "Genetic associations: false or true?" Trends in Molecular Medicine, vol. 9, no. 4, pp. 135-138, 2003.

[179] J. P. A. Loannidis, "Effect of the statistical significance of results on the time to completion and publication of randomized efficacy trials," Journal of the American Medical Association, vol. 279, no. 4, pp. 281-286, 1998.

[180] W. Y. S. Wang, B. J. Barratt, D. G. Clayton, and J. A. Todd, "Genome-wide association studies: theoretical and practical concerns," Nature Reviews Genetics, vol. 6, no. 2, pp. 109-118, 2005.

[181] M. Dean, "Approaches to identify genes for complex human diseases: lessons from Mendelian disorders," Human Mutation, vol. 22, no. 4, pp. 261-274, 2003.

[182] K. M. Hettne, M. Weeber, M. L. Laine, et al., "Automatic mining of the literature to generate new hypotheses for the possible link between periodontitis and atherosclerosis: lipopolysaccharide as a case study," Journal of Clinical Periodontology, vol. 34, no. 12, pp. 1016-1024, 2007.

[183] J. P. A. Ioannidis, "Why most published research findings are false," PLoS Medicine, vol. 2, no. 8, article e124, 2005. 


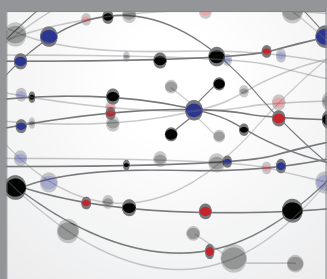

The Scientific World Journal
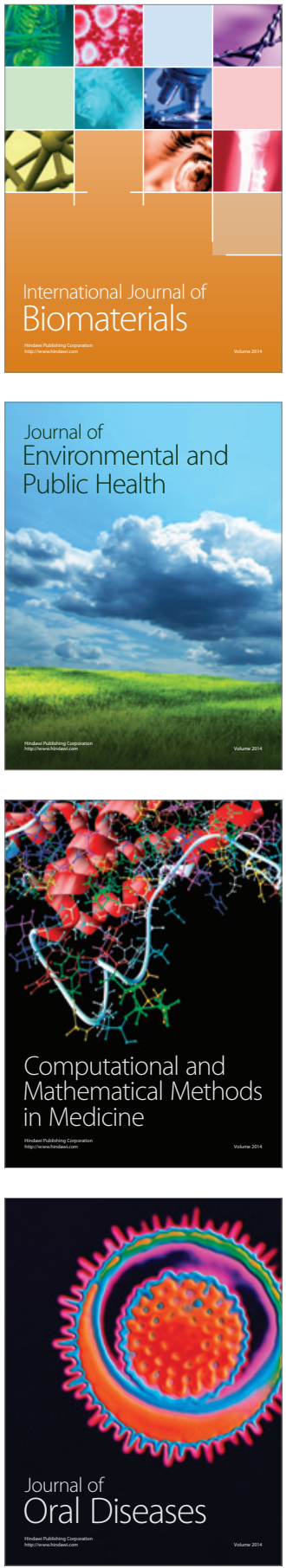
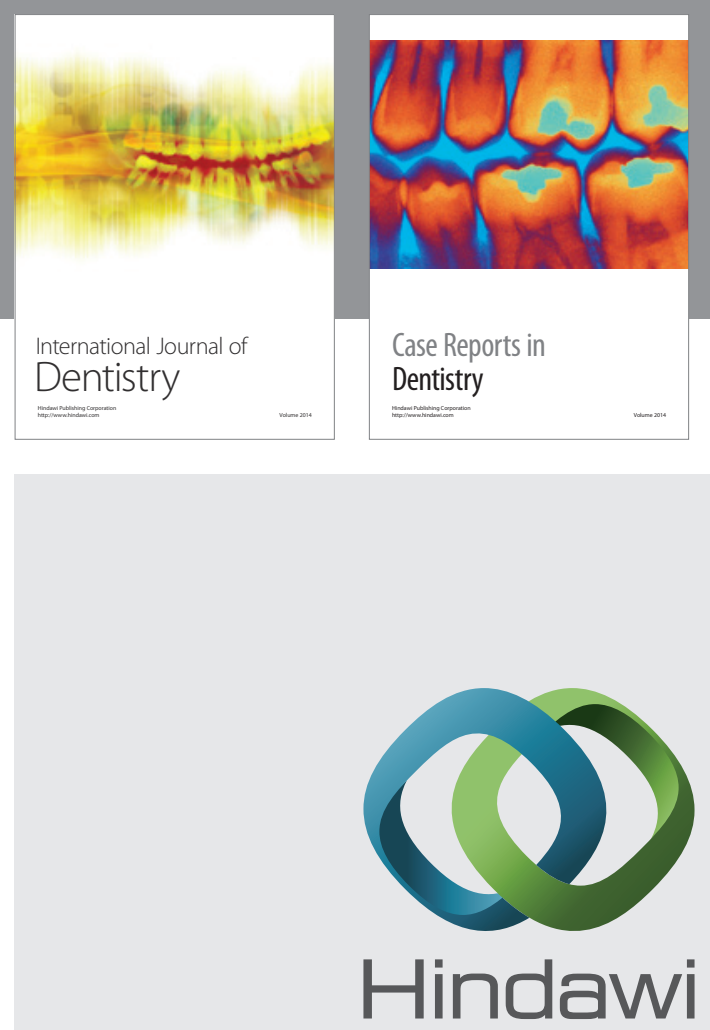

Submit your manuscripts at

http://www.hindawi.com
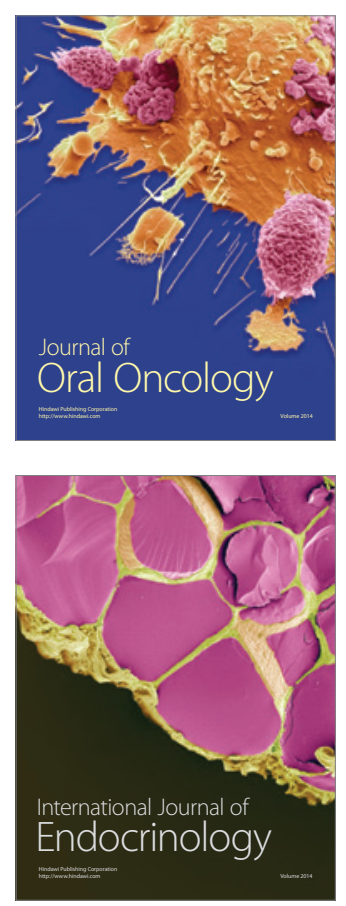
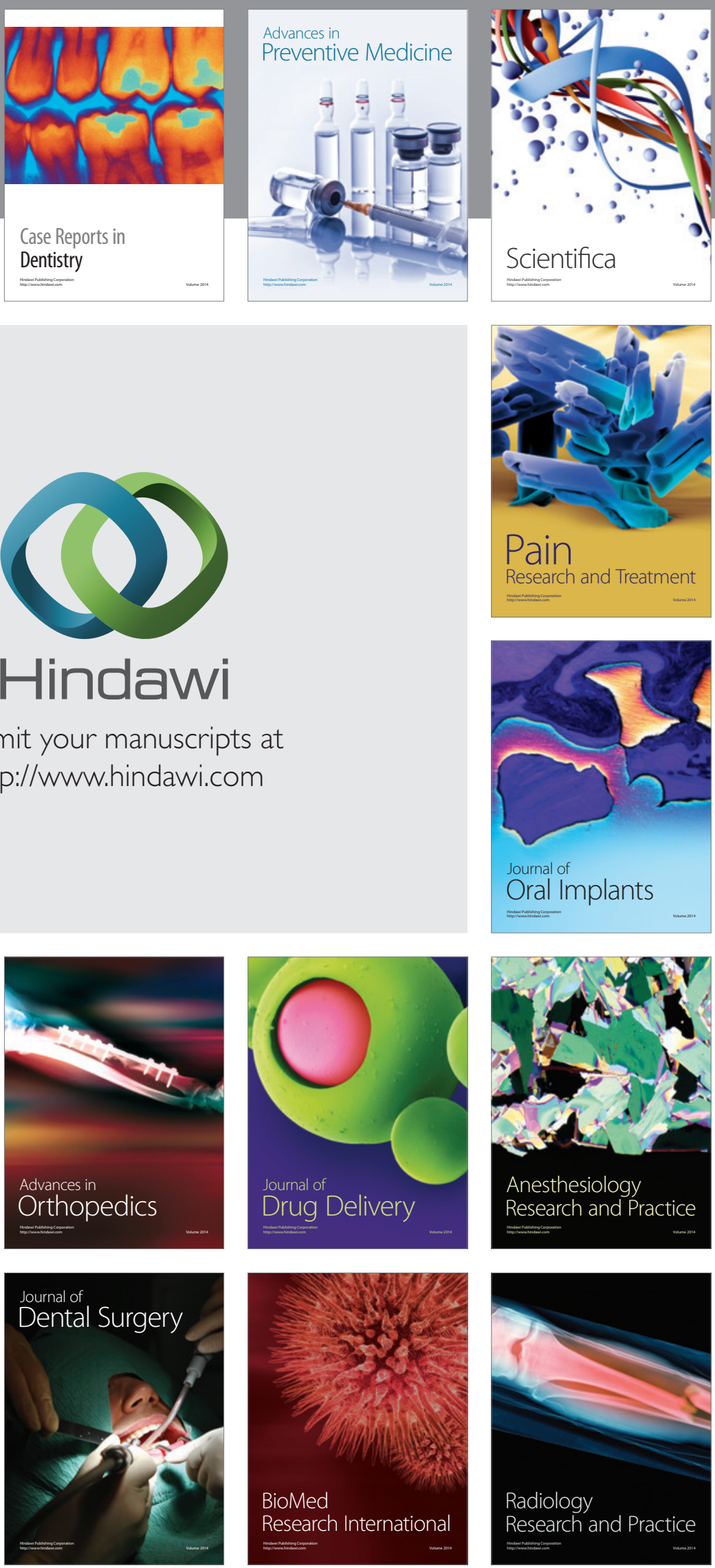